GEOLOGICAL SURVEY CIRCULAR 103

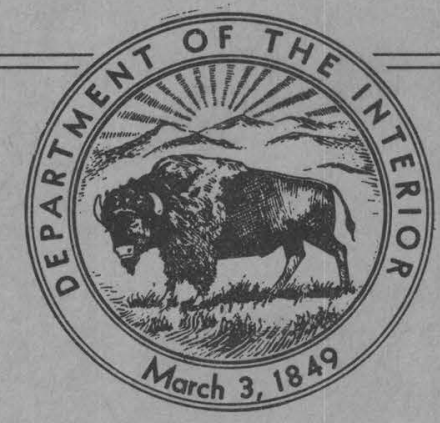

March 1951

\title{
UTILITY OF SELECTED WESTERN LAKES AND RESERVOIRS FOR WATER-LOSS STUDIES
}

By

G. Earl Harbeck, Jr., and others 


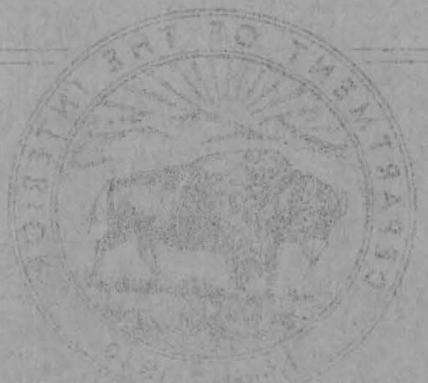

UNITED STATES DEPARTMENT OF THE INTERIOR

Oscar L. Chapman, Secretary GEOLOGICAL SURVEY

W. E. Wrather, Director

Washington, D. C. 


\section{PREFACE}

This report on selected lakes and reservolrs was prepared in the Water Resources Division of the U. S. Geological Survey, C. G. Paulsen, Chief Hydraulic Engineer, under the administrative supervision of $R$. W. Davenport, Chief, Technical Coordination Branch.

Many of the data included in this report were furnished by the district engineers and. geologists of the water Resources Division, U. S. Geological Survey, and by the regional directors of the U. S. Bureau of Reclamation. The wealth of personal knowledge of the particular areas contributed by field representatives of the Geological Survey and Bureau of Reclametion of ten more than compensated for the lack of published information concerning many lakes and reservolrs.

The City Water Department of Oklahoma City, M. B. Cunningham, superintendent and engineer, cooperated to the fullest extent in providing information concerning lake Hefner. The field inspection was gulded by Mr. Cunningham and S. K. Bean, civil engineer for the city water department. F. S. Taylor, in charge of the filter plant, provided many data on operating detalls. Frank Herrmann, office engineer, furnished maps of the reservolr area and operational data from his files. The part of this report describing the geology and ground-water conditions in the Lake Hefner area was written by F. W. Reed. Many climatological data were furnished by W. E. Maughan, U. S. Weather Bureau, Oklahoma City, Okla. The part of this report describing meteorological conditions at Lake Hefner was prepared by members of the staff of R. D. Russell, U. S. Navy Electronics Laboratory, San Diego, Calif.

The discussion of meteorological conditions at Pyramid Lake was prepared by $\mathbf{F}$. R. Anderson, U. S. Navy Electronics Laboratory, San D1ego, Calif. Much of the information on ground-water conditions at Pyramid and Walker Lakes was supplied by T. W. Robinson. Data. on surface inflow were furnished by L. R. Sawyer.

General information on the hydrology of the Bynum Reservoir and Lake Frances area in northern Montana was furnished by $\mathrm{H}$. W. Genger of the Bureau of Reclamation, Great Falls, Mont. J. A. Tidyman of The Valier Company, Valler, Mont., guided the inspecting party on its visit to Lake Frances and provided general climato- logical information and many operational data for the reservoir. The part of this report describirg the geology and ground-water conditions at Bynum Reservoir and Lake Prances was prepared by A. F. Bateman, Jr.

R. A. Work, Irrigation Division, So11 Conservation Service, Medford, Oreg., furmished many data on reservolrs and lakes in that area. Because of his many acquaintances among hydrauIlc engineers and watermasters he was able to provide much essential information.

The geology and ground-water conditions at Big Sage Reservoir in northern California were described by J. F. Poland. T. R. Simpson and I. M. Ingerson of the State of California Division of Water Resources, Sacramento, Calif., provided invaluable data on construction of the dam and operation of the reservolr. Victor Scammon of the state of California Division of Water Resources, Alturas, Calif., gulded the inspecting party on its trip to the reservoir and furnished many operational data. S. B. Kelley, president of the Hot Springs Valley Irrigation District, Alturas, Calif., contributed much historical information on conditions in the reservolr area before and after construction of the dam.

That part of the report describing the geology and ground-water conditions at Lake Mathows and at Elsinore Lake in California was prepared by J. E. Upson. Many hydraulic data for Lake Mathews were furnished by R. B. Diemer and C. C. Elder of the Metropolitan Water District of Southern Califormia. V. P. Pentegoff of the Corps of Engineers, Ios Angeles, was consulted on the geology and ground-weter conditions at Lake Mathews. Current data on depths of Elsinore Lake were furnished by William Brejette of Elsinore. D. R. Crane, clvil engineer, Rlsinore, was the source of information on ground-water levels and well logs in the Elsinore Lake a rea.

B. A. Welss and A. J. Boles of the Imperial Irrigation District, Imperial, Calif., supplied much information on Salton sea (including data on inflow) taken from the files of the 1 rrigation district. The discussion of meteorological conditions at Salton Sea was prepared by members of the staff of R. D. Russell, U. S. Navy Electronics Laboratory, San Diego, Calif. 
• 


\title{
U'TILITY OF SELECTED WESTERN LAKES AND RESERVOIRS FOR WATER-LOSS STUDIES
}

\author{
By
}

G. Earl Harbeck, Jr., and others

INTERIM REPORT

ON

LAKE HEFNER WATER-LOSS INVESTIGATIONS

CONTENTS

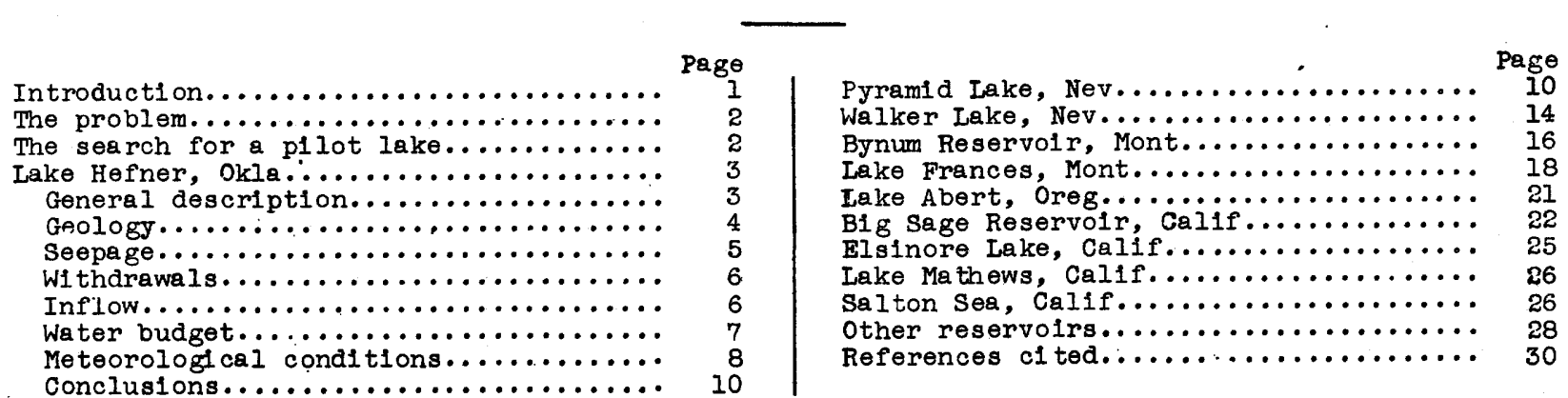

\section{ILLUSTRATIONS}

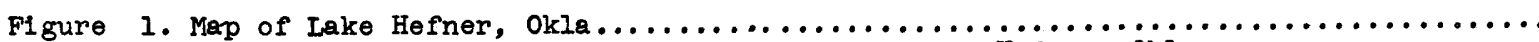

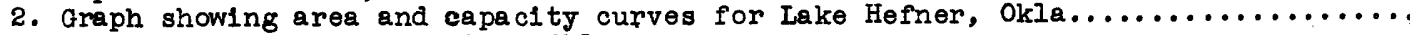

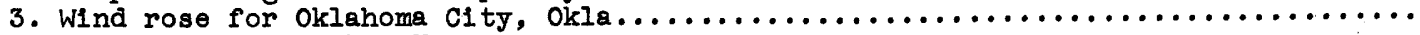

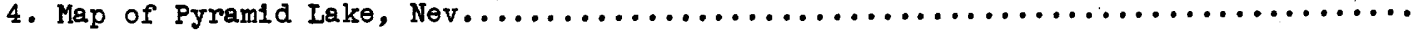

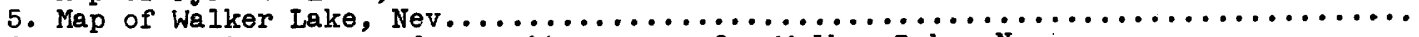

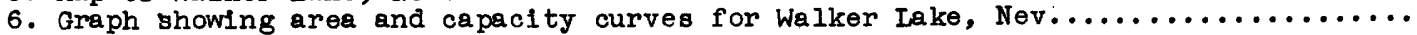

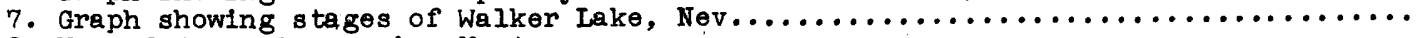

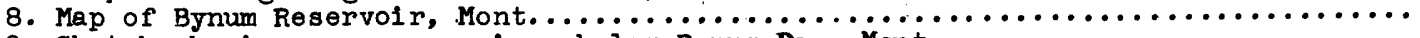

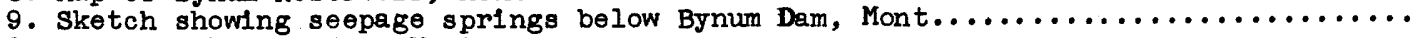

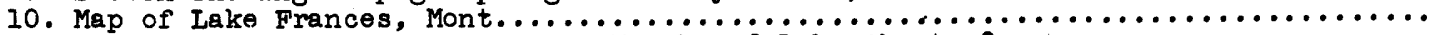

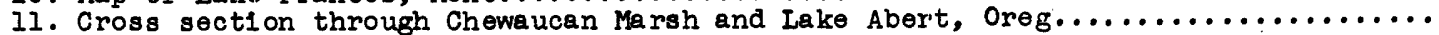

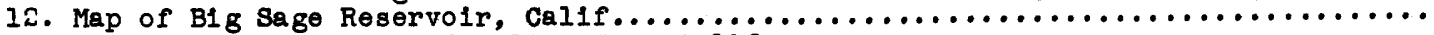

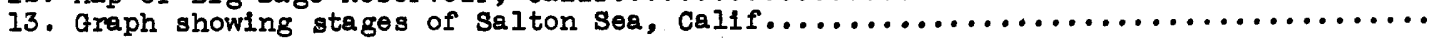

\section{INTRODUCTION}

Spurred by ever-increasing demands, a growing national awareness of the importance of water has arisen. Because the natural distribution of water supplies with respect to both time and place does not necessarily coincide with the demand, storage and transmission of water have long been relied upon to bridge the gap. In addition to the obvious and calculable construction and operation costs of a watersupply project, the cost or economic value of water lost in storage or transmission must be considered. Such losses are unavoldable but can be minimized to a limited extent by proper design and operational procedure.

Evaporation from the water surface and transpiration from vegetation in the reservol $r$ area and along transmission canals are nonrecoverable losses. Practically speaking, evaporation losses from bodies of surface water cannot as yet be prevented, and a knowledge of their magni tude is essential to reservoir design in order that a proper balance may be reached between costs of constmuction and costs of water loss by evaporation. It must be realized, of course, that evaporation costs are but one of many factors to be considered in reservolr design.

Evaporation from reservolrs in the 17 Western States is roughly estimated to be $15,000,000$ acre-feet per year. Th1s does not include evaporation from the water surfaces of natural streams--such evaporation is not properly attributable to reservoir construction.

The amount of water consumed by phreatophytes is probably greater than is generaliy realized. In the 17 Western States, the use of vater by phreatophytes, which is almost entirely 
nonbeneficlal, may be 20 to 25 million acrefeet per year, according to unpublished preliminary figures complied by $T$. W. Robinson of the Geological Survey. This is about twice the annual flow of the Colorado River. Most phreatophytes are found on stream bottoms and valley floors of the intermontane valleys. Although the amount of water consumed by phreatophytes in some reservolr areas is substantial, by far the larger part of the total must be ascribed to other factors. Removal of phreatophytes has been undertaken on an experimental scale in some reservolr areas.

In cortrast to losses by evaporation and transpiration, seepage losses are not true losses in the sense that the water is permanently unavallable for use. Seepage losses may reduce the amount of water avallable for wi tharawal from a reservoir, but the water apparently lost may reappear elsewhere to augment stream flow or may be avallable for withdrawal from wells.

Records of evaporation from pans have long been relied upon and have proved quite useful as indlcators of reservolr evaporation in the absence of more precise information; but their limitations are well known. In addition, many crude equations for the estimation of reservoir evaporation have been proposed, and some have been widely used.

Reservolr losses may be computed as the difference between inflow and outflow (both surface and subsurface), allowing for changes in storage. Proved techniques have been developed for the direct measurement of the last three Items. Reservoir losses thus computed are a residual, and may be subject to large error if inflow, outflow, and changes in storage are large compared with evapotranspiration. A fleld-proved method of measuring reservoir evaporation directly is needed. This report describes the utility of several reservolrs and lakes for the comprehensive studies required to test a number of proposed methods for the direct measurement of evaporation.

\section{THE PROBLEM}

The primary objective of this investigation was to select a reservoir or lake suitable for a comprehensive study of the exchange of energy between the atmosphere and a water surface. Because of their common interest in the basic theory, representatives of the Department of Interior and the Navy Department met in December 1948 to discuss the problem. An agreement was reached by the Bureau of Reclamation and the Geological Survey of the Department of Interior and the Navy Electronics Laboratory of the Navy Department to undertake a joint study of water losses from a pllot lake or reservoir. The ultimate objective was to determine the evaporation from Lake Mead and other western reservoirs and to predict evaporation losses at projected reservoirs from available climatological data.

The contemplated study of water losses, and more particularly evaporation, is described fully by Anderson, Anderson, and Marciano (1950) in a separate report. Three methods are proposed to determine evaporation from the lake or reservoir: (1) water budget, (2) energy budget, and (3) mass transfer. In the water- budget method evaporation is determined by measurements of inflow, outflow, and changes in storage. The energy- or heat-budget method involves the determination of the difference between incoming and cutgoing energy. The masstransfer method requires the measurement of certain parameters related to the factors affecting the transport of water vapor by turbulent diffusion.

The second and third methods have not been tested adequately in the field. In this study the first, or water-budget, method will be used to determine the actual evaporation, thus providing a control for evaluating certain parameters and physical constants needed in the determination of evaporation by the second and third methods.

The need for an accurate water budget is therefore a prime consideration. At first thought it might seem that many lakes and reservolrs exist for which accurate water budyets can be obtained. In a sense this is true because inflow and outflow from many reservolrs can be measured by ordinary methods to within, say, 5 percent. For this study, however, it is necessary to determine accurately the difference between inflow and mutflow. If the inflow and outflow are large compared with evaporation, small errors in their measurement may be large compared with evaporation. A comprehensive evaluation of many lakes and reservolrs was therefore necessary before a site for the water-loss studies could be chosen.

\section{THE SEARCH FOR A PILOT IAKE}

In December 1948, representatives of the Geological Survey, Bureau of Reclamation, and Navy Department discussed specifications for a lake or reservolr to be used for the waterloss studies. In January 1949 the regional directors of the Bureau of Reclamation were asked to submit names of suggested reservolrs or lakes and information concerning them. The suggestions of these regional directors were studied, and inquiries also were made of certain field offices of the Geological Survey.

At that time it was contemplated that the studies would be made only during the summer months when evaporation rates are high. In Callfornia rainfall and runoff are generally low in summer, thus improving the prospects of determining the water budget accurately. The reservoirs first investigated were therefore in California. The results. of these investigations were presented to representatives of the three agencies at a meeting in Boulder C1ty, Nev., on July $21-22,1949$. It was concluded that none of the lakes and reservoirs previously investigated could be used for the study. The requirements were revised and listed in detail at that meeting. In order of importance they are as follows:

\section{Water budget.}

a. The error in the monthly difference between total inflow and outflow, including both surface. and subsurface, allowing for changes in storage (including bank storage), must be less than 5 percent of the best present estimates of the mean monthly-evaporation loss. It is desirable that inflow and outflow be as small as possible during the period of high evaporation. 
b. Infrequent short periods of storm inflow, during which the water budget cannot be determined with the accuracy required under la, can be tolerated.

c. Subsurface inflow and outflow must be negligible compared with evaporation, unless it is known that they can be measured accurately.

d. Substantial bank storage is undesirable.

e. Transpiration losses must be small.

f. An accurate area-capacity curve is needed, but if not available a hydrographic survey can be made.

2. Size.

a. The minimum desirable size is 3 miles in width and 5 miles in length or an a rea of 10 square miles if the water body is nearly circular or if the longer dimension is in the direction of the prevaliling summer winds.

b. The maximum desirable size is 50 square miles if the lake is nearly circular, otherwise 30 square miles. Iarger lakes ( 50 to 200 square miles) may be considered if other requirements are met, but more equipment w1ll be required and cost therefore increased.

3. Shape.

a. A circular shape is ideal. A very irregular shore line is unsatisfactory; an irregular shore line downwind is not as objectionable as one upwind. A long, narrow lake is not satisfactory.

b. An unobstructed expanse of water (few or no islands) extending 5 miles in the direction of the prevaling summer winds is desirable.

4. Depth.

a. Not more than 20 percent of the lake should be less than 5 feet deep (and preferably not less than 10 feet). A deep lake is desirable.

b. Playa lakes should be considered if they meet all requirements except depth.

5. Topographic setting.

a. Low rellef is preferable; lakes in canyons are not satisfactory.

b. The drainage area preferably should be small.

6. Location and climate.

a. An arid region is preferable.

b. There should be falrly long periods of no rainfall during the season of high evaporation, but infrequent storms are are not objectionable.

c. It is preferable, but not essential, that the lake does not freeze in the winter.

A list of lakes was prepared for which more information was required. Many of these were selected because on the maps available they were seen to approach the desired shape and size. This list of lakes and a copy of the specifications was sent to the district offices of the Water Resources Division of the Geological Survey in the Western States. It was requested that information be submitted for each of the lakes listed and for any others that appeared to meet the specifications in most respects. Lakes in the humid region were not considered because of the improbability that the water budget could be determined with the required accuracy.

The replies were reviewed by the three agencles, and at a meeting in San Diego September $12-13,1949$, a number of lakes were selected as needing further investigation. Lake Hefner, near Oklahoma Clty, Okla., was recommended strongly by local Geologi cal Survey engineers and geologists for further investigation. For some of the suggested lakes, a vallable data on which to base a decision were lacking; for some of the others the information indicated that these lakes were worthy of field investigation.

September 14-15, 1949, a reconnaissance was made by Navy plane over western Nevada, southern oregon, and northern California. The party included R. D. Russell, U. S. Navy Electronics Laboratory, San Diego, Calif.; W. O. Smith and G. E. Harbeck, Jr., U. S. Geological Survey, Washington, D. C.; and W. U. Garstka, U. S. Bureau of Reclamation, Denver, Colo. Modern maps of much of the region do not exist, but on the basis of observations from the plane it was possible to eliminate most of the suggested lakes and reservolrs in this area because of unsatisfactory shape, size, or surrounding terrain.

September 16-17, 1949, representatives of the three agencies visited the Salton Sea area. The remaining lakes consldered worthy of field investigation were then visited durIng September 19-30, 1949, by a group that Included W. U. Garstka, W. O. Smith and G. E. Harbeck, Jr., mentioned above, and E. R. Anderson, U. S. Navy Electronics Laboratory, San Diego, Calif. This group was accompanied by representatives of the various district offices of the Geological Survey.

Preliminary reports were prepared to summarize the results of the field investigations. These reports were studied at a meeting held at Boulder City, Nev., October 17-19, 1949. At that meeting Lake Hefner, at Oklahoma C1ty, Okla., was selected as the site for the waterloss studies.

The following reports on lakes and reservoirs in the western States were prepared to make clear the reason for the cholce of Iake Hefner and to make the data collected aval lable to those engaged in studies of evaparation or general limnology.

\section{IAKE HEFNER, OKLAHOMA}

\section{General description}

Lake Hefner is a reservoir completed in 1944 by Oklahoma City for its municlpal water supply: It is in the southeastern part of T. $13 \mathrm{~N} .$, R. $4 \mathrm{~W}$., about 8 miles northwest of the center of the clty. According to areacapacity tables furnished by the city water department, its capacity at full pool (elevation 1,199 ) is 75,681 acre-feet and its surface area 2,595 acres. The lake, fairly regular in shape, is formed by a long horseshoeshaped dam on Bluff Creek. (See fig. 1.) The dam, about $3 \frac{1}{2}$ miles long with a maximum height of 105 feet (from thalweg to road on top of dam), is of rolled-earth fill with a clay core and a seepage collection system.

The lake is supplied principally by a canal from the North Canadian River, although it lies in the Cimarron River Basin. In the Oklahoma City area the North Canadian River is at an elevation several hundred feet higher than the Cimarron River, and only a short diversion canal was needed to permit gravity flow of selected water from the North Canadian 


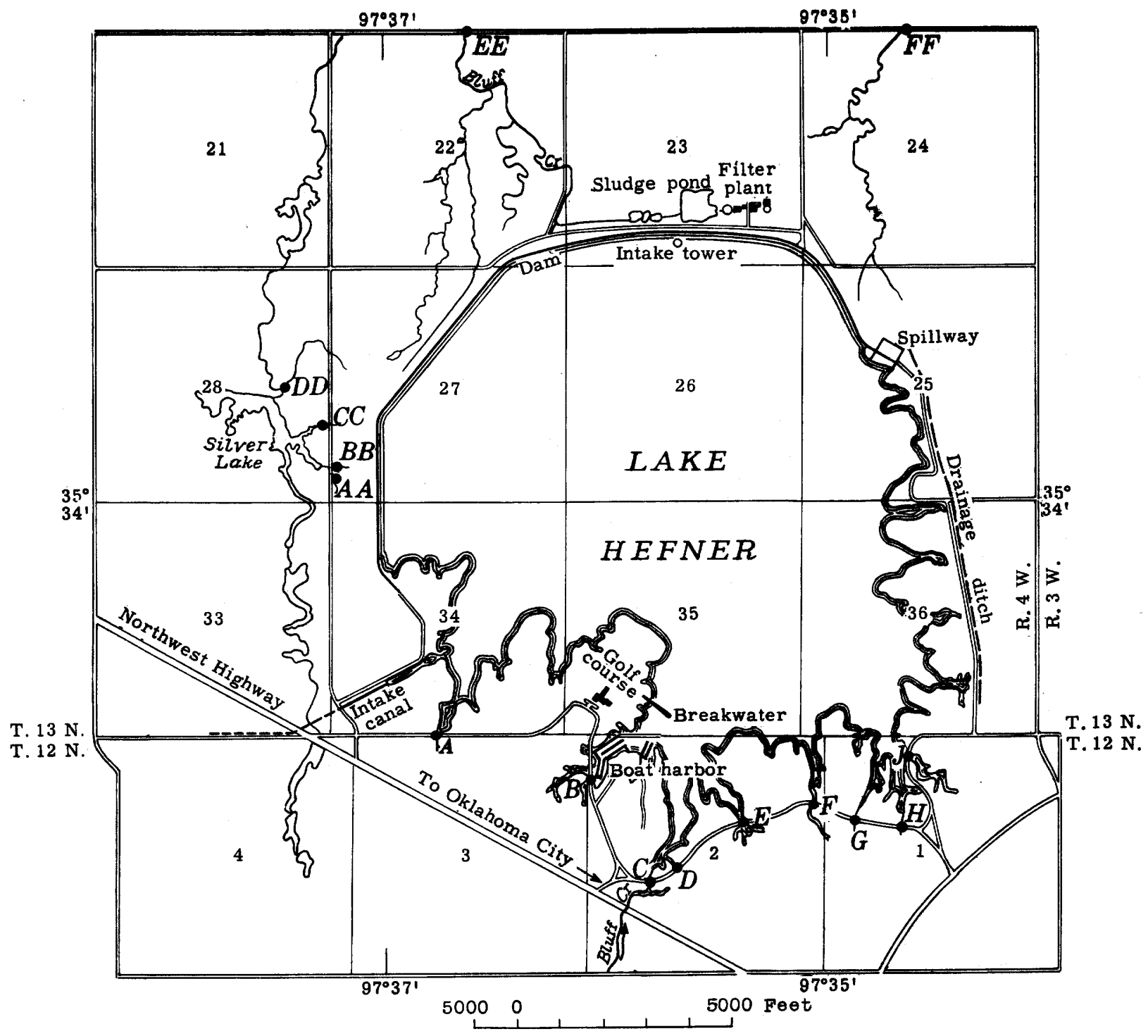

Figure 1. - - Map of Lake Hefner, Okla.

River into Lake Hefner. The natural drainage area of Bluff Creek and other contributing streams above the dam is 3,156 acres, excluding the area of the lake surface. In addition, runoff from an area of about 200 acres discharges into the intake canal and thence into Lake Hefner. The drainage area above the lake is only about 30 percent greater than the area of the lake at full pool.

\section{Geology}

Except where covered by alluvium, the Hennessey shale of Permian age is the surface formation of the Lake Hefner area. It is primarily red shale containing a few thin, lenticular sandstone beds. The formation crops out in a north-south band covering the western third of oklahoma County and dips westward at a rate of about 40 feet per mile. The thick- ness of the Hennessey shale in Oklahoma County ranges from a feather edge aling the surface contact with the underlying Garber sandstone in the central part of the county to about 650 feet at the western edge of the county. As Lake Hefner is near the middle of the outcrop of the Hennessey shale, it is underlain by more than 250 feet of the shale.

Bluff Creek and its tributaries have cut back into a high terrace of the North Canadian River about a mile south of Lake Hefner. This terrace consists of unconsolidated sand, gravel, and clay deposited by the North Canadian River in some past period when the river was at a much higher elevation and probably had a much greater flow than at present. The terrace, now equi valent in area to a single township, was at one time a wide flood plain. The terrace is now being actively dissected by tributaries of both the North Canadian and 
the Cimarron $R 1$ vers, and the divide between the two systems is now on the terrace. The deposits underlying the terrace contain relatively large amounts of water, and many wells, including those supplying the clty of Bethany, have been arilled into 1 t.

The Hennessey shale underlying the reservol $r$ weathers to a dark soll that is readily eroded and shows relatively little rellef. The thin soll layer $1 \mathrm{~s}$ grass-covered. Trees, mostly cottonwoods and willows, are found only along the watercourses where the soll is thicker and capable of storing water.

\section{Seepage}

The Hennessey shale is practically impermeable, and any recoverable water in the shale is belleved to be contained in joints and fractures. Most of the wells tapping the Hennessey shale are farm wells, and the few towns that use water from this formation have wells of low yield. No pumping tests to determine permeablilty have been made on any well in the Hennessey shale, but from the yields of these wells it is evident that the permeability of the sandstones in the Hennessey shale is less than that of the underlying Garber sandstone. Tests on sandstone of the Garber show 1ts permeability to be about 40 gallons per day through an aquifer $I$ foot in thickness and I mile in width under a hydraulic gradient of 100 percent (Melnzer's units). No faults are known to be in the Hennessey shale, and the possibility of seepage of any important quantity of water into or out of the lake through the Hennessey shale seems remote.

Because the regional dip of the strata in this area is westward, a cross section was selected along the western side of Lake Hefner for use in computing approximately the possible magnitude of deep seepage. The length of the cross section from the northern end of the lake to the southern end of the dike is approximately 10,000 feet. Its thickness was assumed to be 100 feet. The hydraulic gradient is assumed to conform to the reglonal dip of 40 feet per mile. The field coefficient of permeablilty was assumed to be 40 gallons per day (Melnzer's units). This is an average figure for the Garber sandstone; the permeebllity of the Hennessey shale is belleved to be much less. From these data, the maximum deep-seepage loss is computed to be 300,000 gallons per day, or 0.9 acre-foot per day. As will be demonstrated later, this figure is of little practical significance when compared with other items included in the water budget. The so-called "wet-weather springs" in the Hennessey shale are caused by rainfall percolating down through the thin soli mantle and along the contact with the shale or sandstone until it reaches the outlet. Very little of the precipitation on the outcrop actually enters the Hennessey shale.

Construction of a series of fish-rearing ponds in the area west of the sludge pond was under way during early 1950. Construction of a canal, a part of the seepage-collection system, necessitated excavation into the previously undisturbed shale to a depth of 3 or 4 feet. The newly exposed shale was dry when inspected in January 1950.
There are, however, small but measurable shallow seepage losses from the reservolr. Because seepage from the reservolr is a functicn of reservoir stage only, it is essential that measurements of seepage be made during dry perlods when there is no surface runoff from the area below the dam. The possibility of defining the relation of seepage to reservol $r$ stage does not appear probable, because the range in reservoir stage is relatively small. However, a serles of seepage measurements at weekly or biweekly intervals during dry periods should provide adequate data on collected seepage.

Any seepage that occurs beneath or through the dike along the northern and western sides of the lake is collected by a series of drains. Along the northern side of the dam, between the west line of sec. 24 and the center of sec. 28, seepage collects and drains into the old Bluff Creek channel below the dam.

Operation of the sludge pond west of the filter plant (see fig. I) at times complicates the determination of seepage in this area. When fliters are washed, the wash water is discharged into the sludge pond, usually causing it to overflow through the morning-glory spillway and temporarily to increase the flow of Bluff Creek below the dam. From time to time small quantities of water are recovered from the sludge pond by pumping. This water does not, however, pass through the raw-water venturi meter. Under normal conditions, filter wash water is not being discharged in to the sludge pond and the recovery pump is not in operation, so that, neglecting evaporation from the pond, the amount of water leaving the sludge pond by spillway overflow and gate leakage is equal to seepage into the sludge pond. A recording gage below the sludge pond is essential to determine when seepage measure ments can be made without the complicating effect of sludge-pond operation. Seepage from the dam will be relied upon to furnish sufficient water to keep the fish-rearing ponds full. It may prove necessary to adjust the measured quantities of seepage for the loss by evaporation from the fish-rearing ponds and from the sludge pond.

Most of the seepage from the west side of the reservoir is collected in a ditch paralleling the dam. It flows northeast along the dike to a point near the north quarter corner of sec. 27 and thence in a northerly direction. A small pond in the NWt sec. 27 also drains northeast, paralleling the main drainage ditch. The two seepage channels join near the center of sec. 22 (see fig. 1) and reach the Bluff Creek channel at a point approximately 1,000 feet south of the north line of sec. 22 . Several small seepage areas were noted in the SW $\frac{1}{4}$ sec. 22. At one of these, a spring issues from a small depression in an open field and flows into the westernmost of the two seepage channels previously described. There are several uncontrolled farm ponds--perhaps an acre in extent-in the $\mathrm{S} \frac{1}{2}$ sec. 22. They are kept filled by seepage and overflow continuously. The flow of Bluff Creek where it crosses the highway along the north line of sec. 22 (Iocation $\mathrm{EE}$ on fig. 1) includes the seepage from the area along the northern side of the reservol $x$, west of the filter plant. The seepage flow measured at EE on April 7, 1950, was 0.89 cubic foot per second, or 1.8 acre-feet per day. 
Along the west alde of the reservolr a number of small seepage areas discharge into a tributary. that joins Bluff Creok about a miles below the dam. Seepage can be measured at locations $A A, B B$, and $C C$ (seo f1B. 1) at culverts under the highway. A fourth seep, DD, has its origin in marshy areas on both sides of the highway, and can be measured fust above 1 ts confluence with silver Lake outflow. The total flow of the four seeps, $A A-D D$, inclusive, on April 7, 1950, was 0.07 cuble foot per second, or 0.1 acre-foot per. day.

In the area east of the filter plant several seepage areas discharge into a small stream channel. During a period of dry weather it was noted that small tributaries from the west or reservoir side of the stream continued to flow, but tributaries from the east side were dry. It was therefore concluded that the observed flow was seepage from the reservoir. There are several small marshy areas below the spillway in the WW $^{\frac{1}{4}}$ sec. 25. Discharge from these marshy areas flows under Hefner Road near the south quarter corner of sec. 24. The flow from a small seep in the SW sec. 24 joins the seepage from the spillway area just below Hefner Road. Other minor seepage areas in sec. 24 contribute minor amounts, and the total seepage can be measured at point FP on the north Iine of sec. 24. (See f1g. 1.) The measured seepage flow at FF on January 25,1950 , was 0.17 cuble foot per second, or 0.3 acre-foot per day.

\section{W1 thdrawa ls}

Water is released from Iake Hefner through a 48-inch raw-water main. Outflow rates are measured with a venturi meter. The recording device is actuated by a mercurial manometer, and the difference in head, converted to equivalent rate of flow in million gallons per day, is recorded on a circular chart in the filter plant. A cam-actuated totalizing device registers total flow. Although the manufacturer's rating for the venturi meter is quite adequate for the needs of the city water department, it is essential that, for the purposes of this sturiy, the venturi meter be calibrated in order that reservolr withdrawals may be measured as accurately as possible. It is estimated that, after calibration, the error in measuring withdrawals will not exceed 3 percent and may be substantially less.

Reservoir withdrawals are the major item in total outflow from Lake Hefner. Combined capacity of the three pumps is 24 million gallans per day ( 73.7 acre-feet per day), but filter capacity limits the maximum possible withdrawal to a peak rate of approximately 22 million gallons per day. During daytime hours in the summer months the ordinary peak rate of flow usually is 18-20 mililon galions per day, with a total of 15 million galions for the entire 24-hour period. During nonsummer months pumpage is somewhat less, averaging perhaps 6 million gallons per day.

\section{Inflow}

The major source of inflow to Lake Hefner is the canal from North Canadian River. (See fig. 1.) During the 3-year period ending September 30 , 1949, substantial volumes of inflow occurred during 11 perlods totaling 64 days, or an average of 21 days per your. Avorage inflow on those day was approximately 1,000 acre-feet. Because of the selatively large volumes of water concerned, it 1s not certain that the water-budget accuracy requirement can be met on days when oanal Inflow 1s of this magnitude. A 5-percent error in measuring inflow would amount to 50 acre-feet, which is approximately equal to the average daily evaporation. With frequent dischargo mea surements during the infrequent perlods of high inflow it may be possible to compute weekly reservolr losses w1 th suffl clent accuracy.

A small amount of natural flow also reaches the reservoir through the intake canal. The canal cuts across the previously described Betheny terrace and intercepts part of the surface- and ground-water flow that formerly reached the stream that enters Bluff Creek as a tributary from the west several miles below the dam. Part of the canal is pavod, and drain tile has been installed beneath the peved section to .prevent "floating." The water thus drained is discharged into the afore-mentioned Bluff Creek tributary, which bypasses the lake. A small amount of ground water drains into the canal and is conveyed into Lake Hefner. Storm munoff from an area of approximately 200 acres also drains into the canal. A recording gago and an artificial control are required to measure this flow. The best site appears to be at the point of emergence of the siphon, about one-half mile above the lake, where wide broad-crested concrete weir has been provided. As normal ground-water discharge is about 0.5 cubic foot per second, or 1 acre-foot per day, the existing concrete welr is too insensitive, and a small rectangula $r$ weir is needed for precise determination of low flows.

Excluding the intake canal, the natural drainage area above full pool elevation of 1,199 feet is 3,156 acres, based on a transitstadia determination by $s$. K. Bean, clvil. engineer of the Oklahom City Water Department. of the total area, 2,484 acres 11 es above the road that encircles the southern end of the lake. The size of the area lying between the road and the lake varies with reservoir stage but is 672 acres when the lake stage is 1,199 feet.

The major stream that flows into the reservoir is Bluff Creek, which has a drainage area of 1,037 acres above the enciling rosd. The headwater tributaries of Bluff Creek drain part of the Bethany terrace, and the perennial flow of Bluff Creek is derived from ground water in that area. A recording gage and artificial control at the road bridge (Iocation $C$ on fig. 1) are required to measure Bluff Creok flow.

The remainder of the storm runoff is carried under the encircling road by concrete culverts, thus limiting the number of points at which inflow must be measured. Records of flow are required at 8 points (locations $A, B, D, F, F$, $G, H, J$ on fig. 1). These may be obtained with sufficient accuracy if a weir is installed at the entrance to each culvert. A crest-stage gage is required at each location to record the peak stage reached during storm runoff. One or more points on the recession hydrograph can be obtalned by direct observation. Based on conti muous records of Bluff creek flow and rainfall in the reservoir area, the discharge 
hydrograph at each inflow polnt may be estimated w1 th sufficlent accuracy.

According to S. K. Bean, Inverts of all culverts have been set at elevation 1,199, the maximum reservolr stage. Th1s has resulted in the formation of small pond areas on the upstream side of several culverts. Flow through the culverts takes place only when the pond levels have risen to the culvert invert elevation. During many storms munoff is insufficient to raise the ponds to the overflow point, and inflow to the lake does not occur.

The possible error in measuring storm inflow to Lake Hefner is small compared to the possible error in measuring rainfall on the lake surface. Discharge of Bluff Creek and the intake canal can be measured with sufficient accuracy except possibly for a few short periods of high flow each year. Estl tes of flow through the culverts and from the ungaged area are subject to fuirly large percentage errors, but the actual magnitude of those errors is small. During minor floods, runoff is seldom greater than one-third to one-half of the flood-producing rainfall. On an anniual basis the difference between rainfall and runoff is even more striking. Rainfall at Oklahoma City, from U.S. Weather Bureau records, averages 31.76 inches annually. Average annual runoff in this area is between 2.5 and 5.0 inches, according to langbein (1949, pl. i). The total dra lnage a ree above full-pool elevation is 3,156 acres, compared w1th a lake-surface area of 2,595 acres, as taken from the area-capaci ty table of the city water department. As the area of the lake surface is nearly as great as that of the tributary drainage basin, rainfall on the lake surface is a much larger 1 tem in the water budget than is munoff from the area above the lake. Therefore, possiblo additional refinements in measuring inflow do not appear justifled.

Rainfall on the lake is a large 1 tem in the water budget, and a dense network of rain gages will be required. It is proposed to place recording rain gages at each of the meteorologlcal stations and 18 nonrecording gages spaced as uniformly as possible around the lake. It is planned to install a recording rain gage on the barge in the middle of the lake on which meteorologlcal equlpment w1ll be placed. A muni cl pal golf course is under construction on the south side of Lake Hefner. It is proposed to 1 rrigate the new greens and fal rways w1th water pumped directly from the lake. The maximum pumpege contemplated is 250,000 gallons, or $\Gamma .8$ acre-foot, per day. The metered withdrawals from the lake present no problem, but the possibility of return flow from irrigation cannot be ignored. Records of water-level elevations at several test wells in the area between the golf course and the lake will be necessary to determine whether return flow is reaching the lake and, if so; to estimate the quantity. It appears improbable that the quantity will be sufficiently large to warrant inclusion in the water-budget calculations.

\section{Water budget}

An approximate average monthly water budget has been estimated in order to illustrate the relative magnitude of the quantities involved, when there are no diversions from North
Canadian River. Istlmates of the probable upper limit of measurement errors have beell shown. The reservolr is assumed to be full at the beglnning of the month (contents 75,681 acre-feet, surface area 2,595 acres, from c1ty water department area-capacity table.) (See flg.2.) Annual reservolr evaporation at Oklahoma C1ty is estimated to be about 66 inches; January evaporation is estimeted to be 7.5 inches and July evaporation to be 10.2 inches, according to the Amerlcan Soclety of C1vil Englneers (1949, p. 127 , table 15). At these rates monthly evaporation from Lake Hefner averaces 324 acre-feet diring January and 2, 210 acre-feet durlng July.

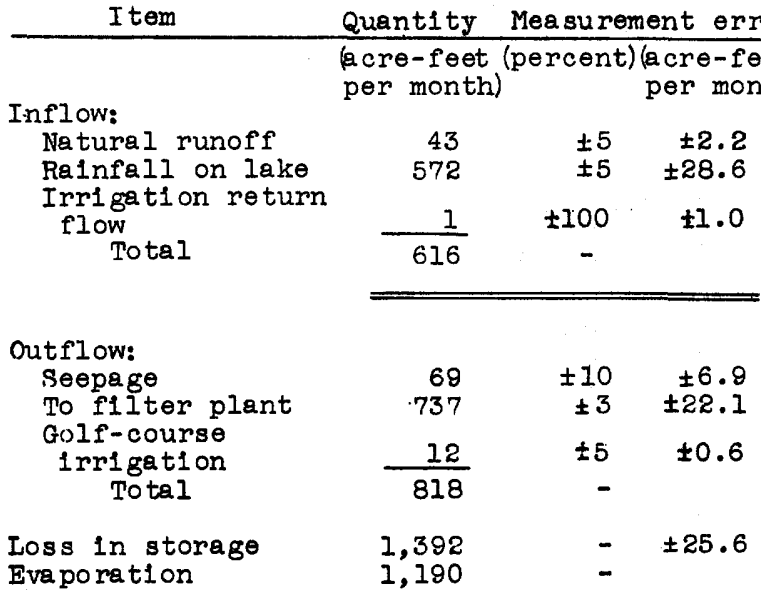

The loss in storage was computed by subtracting inflow from the sum of outflow plus evaporation. The error was computed by assuming that the error in the measured change in atage w1ll not exceed 0.01 foot.

It is required that the error in the difference between inflow and outflow shall not exceed 5 percent of the mean monthly evaporation. The error in measuring change in contents must, of course, be included. For short periods of time, change in contents becomes the controlling factor. During pericds of hish winds, it is doubtful that changes in stage can be measured closer than 0.01 foot. On this besis dally evaporation as crmputed from the water budget is subject to a possible error of 65 percent, and weokly evaporation an error of 9 percent. A week, therefore, appears to be the shortest interval for which dependable evaporation figures can be obtained, exce it during periods when nocturnal winds are light, so that midnlght stages can be accurately determined.

The errors shown in the table are belleved to represent the maximum error to be expected. For average months the errors in monthly values in any item may be expected to follow the normal law of error. The variance of the sum of a number of items is the sum of the variances of the individual items. If the errors in the individual items be conservatively considered to represent two standard deviations (1.e., it is expected that they may be exceeded once in 20 times), it is also to be expected that the error in their sum will exceed 44.9 acre-feet only once in 20 times, on the average. The maximum allowable error in the sum is 59.5 acre-feet, which is 5 percent of the evaporation. The probability is 8 in 1,000 or a little less than 1 in 100 that this figure will be exceeded. The probablilty that the maximum 3 error in all items will occur simultaneously is 


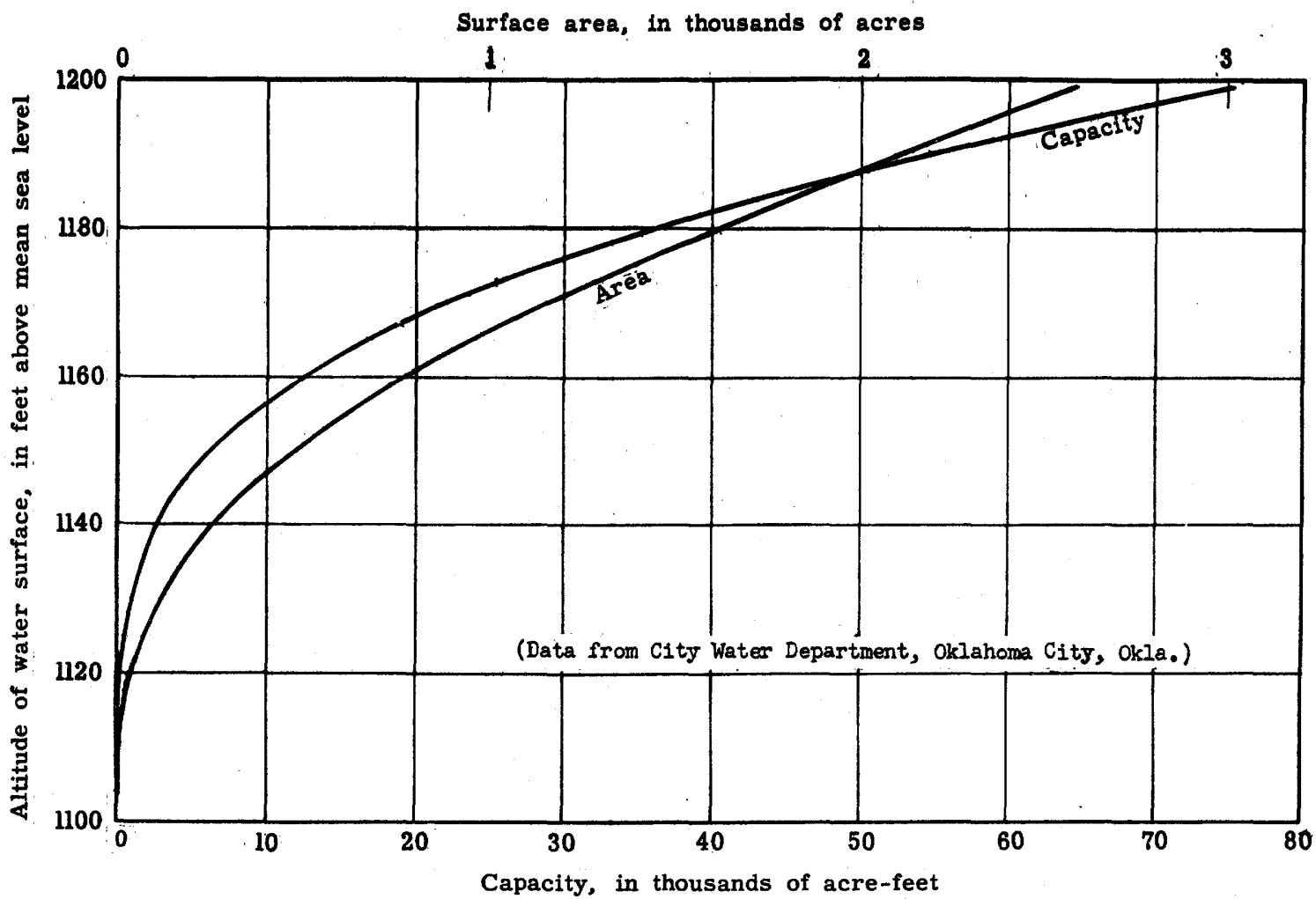

Figure 2. -- Graph showing area and capacity curves for Lake Hefner, Okla.

It is anticipated that during major storms it will be impracticable to obtain sufficiently accurate records of rainfall and runoff. Average daliy evaporation is approximately 40 acrefeet. An inch of rainfall on the lake surface amounts to 216 acre-feet at full pool. A 5percent error in the determination of a verage rainfall amounts to 10.8 acre-feet, or more than 25 percent of the dalis evaporation. The error in measuring total storm runoff from the gaged and ungaged areas is probably greater than 5 percent, but runoff is smali in compar1son with rainfall. The accuracy of the water budget during major storms is limited primarily by the accuracy of the determination of rainfall on the lake. A study of the areal var1ablil ty in rainfall as measured by the network of rain gages will indicate the magitude of the possible error in the determination of preolpitation on the reservolr surface.

The frequency of storm rainfall has been invest1 gated. For the 10-year per1 od 1939-48, the frequency of dally preclpitation is as follows:

\section{Daily precipitation in inches}

$$
\begin{aligned}
& 0.50 \text { - } 0.99 \\
& 1.00 \text { and greater }
\end{aligned}
$$

Average number of occurrences per year

\section{3}

10

The number of days which had rainfall of 1 inch or greater was significantly greater for the months of April, May, and June. A succession of several days of heavy rainfall was not. uncommon. Therefore, al though on the average 1t may be expected that daliy precipitation will be 1 inch or more on 10 days each year,. the number of storm periods would be somewhat less.

The area-capac1ty table for Lake Hefner used by the city water department was prepared on the basis of a topographic survoy made prior to the construction of the dam. Although the existing table is entirely adequate for operational purposes, a complete hyarographlc survey of the lake wili be required to determine the amount of deposition of sediment, if any, ol nce the reservoir was filled, and the amount of overburden removed for construction of the embankment. The resurvey should be particularly precise in the area covered by the top few feet of water in order that the changes in volume and area resulting from small changes in stage may be accurately determined.

\section{Meteorological conditions}

Meteorological conditions at Lake Hefner are favorable for water-loss studi es. Because the surrounding topography is gently sloping, the. wind structure is not distorted by mechant cally induced turbulence except in the area near the dike. Northerly and southerly winds predominate, as shown in figure 3 . The following table (Weather Bureau, Oklahoma City) shows the average monthly wind speeds at the $J$. $S$. Weather Bureau station in the residential section of Oklahoma city. 


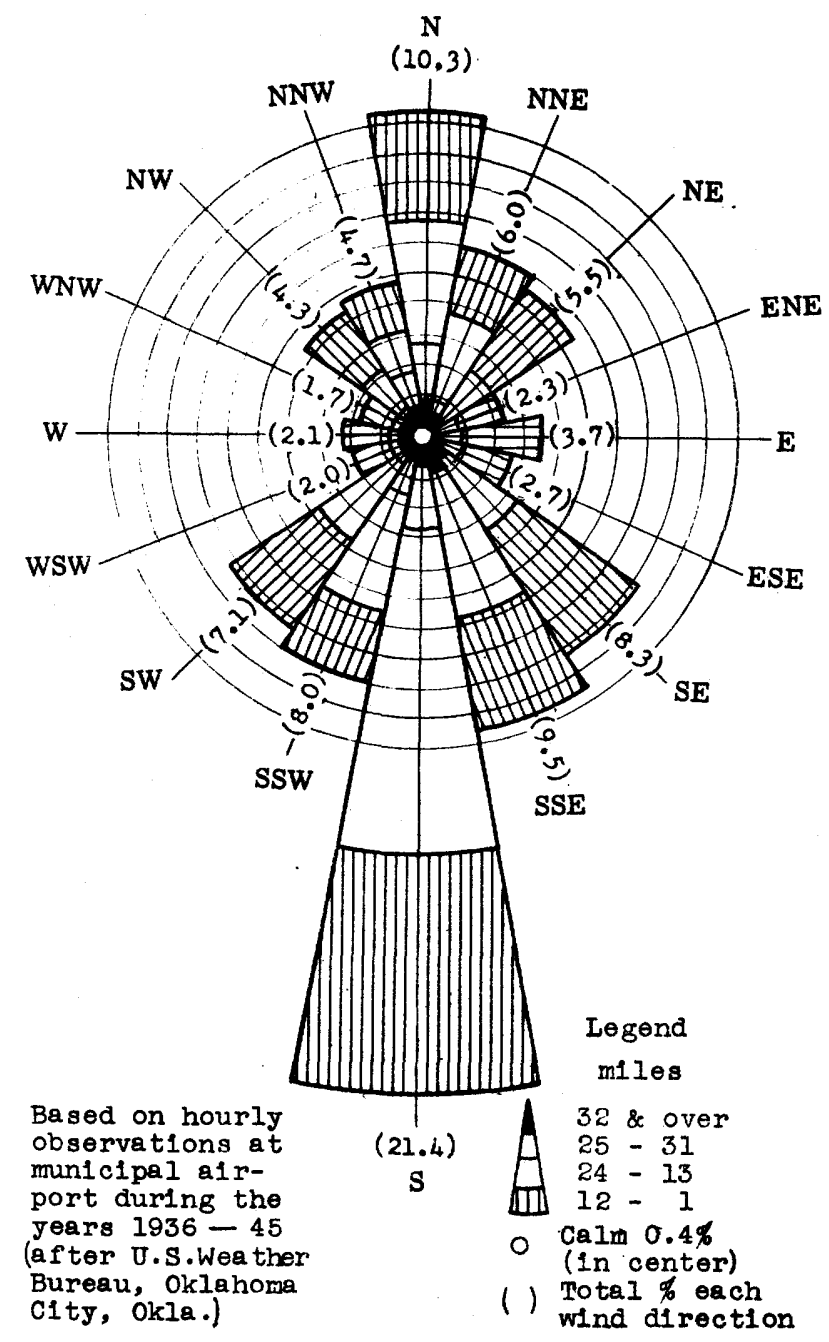

Figure 3. -Wind rose for Oklahoma City, Okla.

\begin{tabular}{ll|lc} 
Month. & $\begin{array}{c}\text { Average } \\
\text { wind } \\
\text { speed } \\
\text { (miles per } \\
\text { hour) }\end{array}$ & Month & $\begin{array}{c}\text { Average } \\
\text { wind } \\
\text { speed } \\
\text { (miles per } \\
\text { hour) }\end{array}$ \\
Jan. & 11.2 & July & 9.3 \\
Feb. & 12.2 & $\begin{array}{l}\text { Aug. } \\
\text { Sept. }\end{array}$ & 9.0 \\
Mar. & 13.3 & Oct. & 10.3 \\
May & 13.1 & Nov. & 11.1 \\
June & 11.6 & Dec. & 11.1 \\
& & Yearly avg. & 11.1
\end{tabular}

The winds at Lake Hefner are expected to have a speed of approximately 5 miles per hour greater than those observed at the city station. The maximum 5-minute average speed at Lake Hefner may approach 60 miles per hour.

The humidity at Oklahoma $C_{i}$ ty is shown in the following table (Weather Bureau, Oklahoma City). Prior to July 1939 observations were made at the city office, but since 1939 the data have been obtained at Will Rogers Field, approximately 7 miles southwest of the c1ty office.

\begin{tabular}{lcccc} 
Month & \multicolumn{4}{c}{$\begin{array}{c}\text { Relative humidity } \\
\text { 1n percent at }\end{array}$} \\
& \multicolumn{5}{c}{ indica ted time } \\
& 3:00 $6: 30$ & 12:30 & $6: 30$ \\
& a.m. a.m. & p.m. & p.m. \\
Jan. & 77 & 80 & 62 & 65 \\
Feb. & 74 & 79 & 57 & 60 \\
Mar. & 71 & 76 & 50 & 53 \\
Apr. & 73 & 77 & 51 & 52 \\
May & 77 & 82 & 57 & 59 \\
June & 79 & 82 & 55 & 57 \\
July & 73 & 79 & 48 & 51 \\
Aug. & 71 & 79 & 47 & 51 \\
Sept. & 69 & 81 & 51 & 55 \\
Oct.: & 72 & 79 & 53 & 57 \\
Nov. & 72 & 78 & 56 & 61 \\
Dec. & 76 & 80 & 61 & 66 \\
Year & 74 & 79 & 54 & 57 \\
Years of record & 9 & 58 & 31 & 58
\end{tabular}

Two series of humidity measurements were made at Lake Hefner on September 30, 1949, using a sling psychrometer. Between 10:00$10: 15 \mathrm{a} . \mathrm{m}$. at the upwind shore the wind was from south-southeast and its speed was est1mated at 20 to 25 miles per hour. At the downwind shore the wind was also from south-southeast; 1ts speed was 30 to 35 miles per hour and it was very gusty. Average wave heights on the lake were 1.5 feet, w1 th a maximum of 4 feet. The wave length was estimated to be 15 feet. Wave data were estimated from the downwind shore. Measurements of humidity at this time showed a vapor-pressure difference (downwind minus upwind) of 2.9 millibars. Relative humidity at the upwind location was 42 percent; at the downwind location, 53 percent.

The second set of measurements was made in the afternoon, from $2: 15$ to $2: 30 \mathrm{p} . \mathrm{m}$. The wind was south-southeast at 15 miles per hour. Wave heights were approximately 0.5 foot. The vapor pressure difference was 2.0 millibars. Relative humidity at the upwind location was 32 percent; at the downwind location, 43 percent. The weter temperature at this time was $69^{\circ} \mathrm{F}$., indicating a vapor-pressure difference of 19.7 millibars between the vapor pressure of saturated air at the temperature of the water and the actual vapor pressure of the air at psychrometer level. The grass on the south side of the lake averages about 12 inches in height, indicating a roúghness parameter of approximately 6-7 centimeters for 11 ght winds, and 3-4 centimeters for strong winds that flatten the grass and thus create a smoother surface.

A third series of humidity measurements were made on October 3, 1949. The wind was southsouthwest, 5 to 10 miles per hour at the upwind (south) shore, 0 to 3 miles per hour at the downwind shore. The average of 8 readings at the upwind location indicated the relative humidity was 77 percent; the average of 13 readings at the downwind location indicated the relative humidity was 82 percent. The vapor-pressure difference (downwind minus upwind) was 1.4 millibars.

The humidity measurements, and particularly the last set, which were made under conditions of light winds and high humidities, indicate that the vapor-pressure difference is easily measurable. The humidity equipment to be used will measure a difference of 0.2 mllibar. 


\section{Conclusions}

Lake Hefner is belleved to meet more of the requirements for the water-loss studi os than any othor of the reservoirs investigated. A somewhat larger lake would be desirable, but Lake Hefner is reasonably regular in shape, and preliminary meteorological observations Indicate that humidity difierences across the lake are meagurable. The general wind stmucture is uncomplicated by orographic effects. More detalled investl gations are required of certain factors affecting the water budget, such as a more precise determination of possible deepseepage losses and a test of the venturi meter rating. A careful study of the relative magnitudes of the quantities involved in the water budget and of the errors of measurement leads to the conclusion that the evaporation from Lake Hefner can be determined by the waterbudget method with acceptable accuracy for a large part of the time. It was on the basis of these facts, therefore, that the reprosentatives of the Geological Survey, Bureau of Reclamation, and Navy Department agreod thet the water-10ss studies should be conducted at Lake Hefner.

\section{PYRAMID IAKE, NEVADA}

Pyramid Lake lies in a closed basin in Washoe County, Nev., approximately $40 \mathrm{miles}$ northeast of Reno. It 1 s supplied by inflow from Truckee R1ver, but since shortly efter the turn of the century, much of the natural flow of Truckee River hes been diverted for irrigation, thus accelerating the decline in lake levels that has continued since about 1870. The lake is now approximately $8 \mathrm{mlles}$ Wide and 22 miles long.

Pyram1d Laice is sheltered by mountain ranges-the Virglinia Range rising on the west to more than 4,000 feet and the Lake Rarige on the east side to more than 2,000 feet. (See f1g. 4.) Russell ( $1885, \mathrm{pl} .3$ ) noted, on each side of the long axis of the lake, the existence of a major fault marked by the edges of upheaved blocks of besalt. The lake occuples part of the bed of the Plelstocene Lake Lahontan, which was first described in detall by Russell (1885) who visited the region in 1881-83. According to Jones (1925, p. 3), "only the valleys in the western portion of Nevada were occupied by Lake Lahontan. The great peninsulas and 1 slands formed by the mountain ranges $1 \mathrm{m-}$ pressed an exceedingly irregular shore line upon the lake. At the time of the greatest expansion of the water surface it covered an a rea of about 8,500 square miles, and as the surface of the lake fell and uncovered the different divides, it separated into a number of independent smaller bodies of water. At present these subsidiary basins are all in a state of dessication. Some retain permanent bodies of water, such as Pyramid, Winnemucca, and Walker Lakes; others may go entirely dry in exceptionally dry years, as Carson,. Honey, and Humboldt Lakes; still more are playss, covered with water for only brief periods of the year, as the Black Rock and Smoke Creek Deserts." Winnemucca Lake, however, has been dry since 1939.

The lacustrine sediments deposited during the Iife of Lake Lahontan were classified by Russell (1885, p. 125) into three divisions: upper lacustral clays, medial gravels, and lower lacu stral clays. The lacustral marly clays are fine and evenly laminated. Near the mouth of Truckee River only the upper clays are exposed. On the basis of a fleld examination, these beds are consldered relatively Impermeable. Probably the present lake bed 18 composed of essentialiy slmilar deposits.

The surface-water supply of Pyramid Lake $1 \mathrm{~s}$ derlved from Truckee River. The average daliy discharge of Truckee River into the lake $1 \mathrm{~s}$ estimated to be approximately 50 cublc feet per second, or 36,000 acre-feet per year. During the flood of December 1937, peak discharge of Truckee River at Reno was approximately 13,000 cuble feet per second, Indicating that much larger volumes of inflow may occur, but flows of this magni tude are inf requent and of short duration.

Also flowing into Pyramid lake are a number of small, ephemeral streams that drain an area of approximately 3.5 square m1les. Average annual runoff in this region $1 \mathrm{~s} 0.251 \mathrm{nch}$ or less, according to Langbeln (1048, pl. 1). Ualng the flgure of 0.25 inch, a verage annual inflow from thls source is 4,000 acre-feet.

There 1s Iittle information avallable on the voluue of ground-water flow into Pyramid Lake. Two small springs were observed near the water's edge on the southwest side of the lake. A distinct odor of hydrogen sulfide was noted. Total discharge from the two aprings was est1mated to be about 0.5 cublc foot per second, or 400 acre-feet per year. The proprletor of an inn at Sutcliffe, on the west shore of the lake, reported that domestic water supplies are obtained from springs in the mountalns and from wells in the alluvial fans. The Soutiern Pacific Lines have a well near sutcliffe for feed-wa.ter supply and another at Big Canyon.

The eastem side of the lake is inaccessible by road and was not inspected. The aerial reconnal ssance on September 14,1949 , revealed no perennial streams flowlng into the lake, but ground-water conditions could not be determined.

There are evidences of anclent hot springs near the south and north ends of the lake. It is reported that there are hot springs in the lake on the north side nf Pyramid Island; steam is reported to rise from this area on cold days. Russell ( 1885, p. 60 ) noted severel hot springs rising from the bottom of the lake and along the base of the tufa crags on the north side of the peningula at The Needles near the north end of Pyramid Lake. No such springs were observed on September 19, 1949.

There is believed to be no movement of underground water from Warm Springs and Winnemucca Valleys to Pyramid Lake, according to D. A. Phoenix, who has studied the area and states that the pass from Warm Springs Valley to Pyramid Lake contains fine-grained lake sediments.

Areas of phreatophytes along the southern, western, and northern shores of Pyramid Lake are relatively minor. On the west shore opposite Anaho Island a patch of salt cedar covers approximately 1 acre. Approximately 2 miles north of Sutcliffe, on the west shore, a verdant area of not more than 5 acres is evidence of a small ground-water supply. An irrigated 


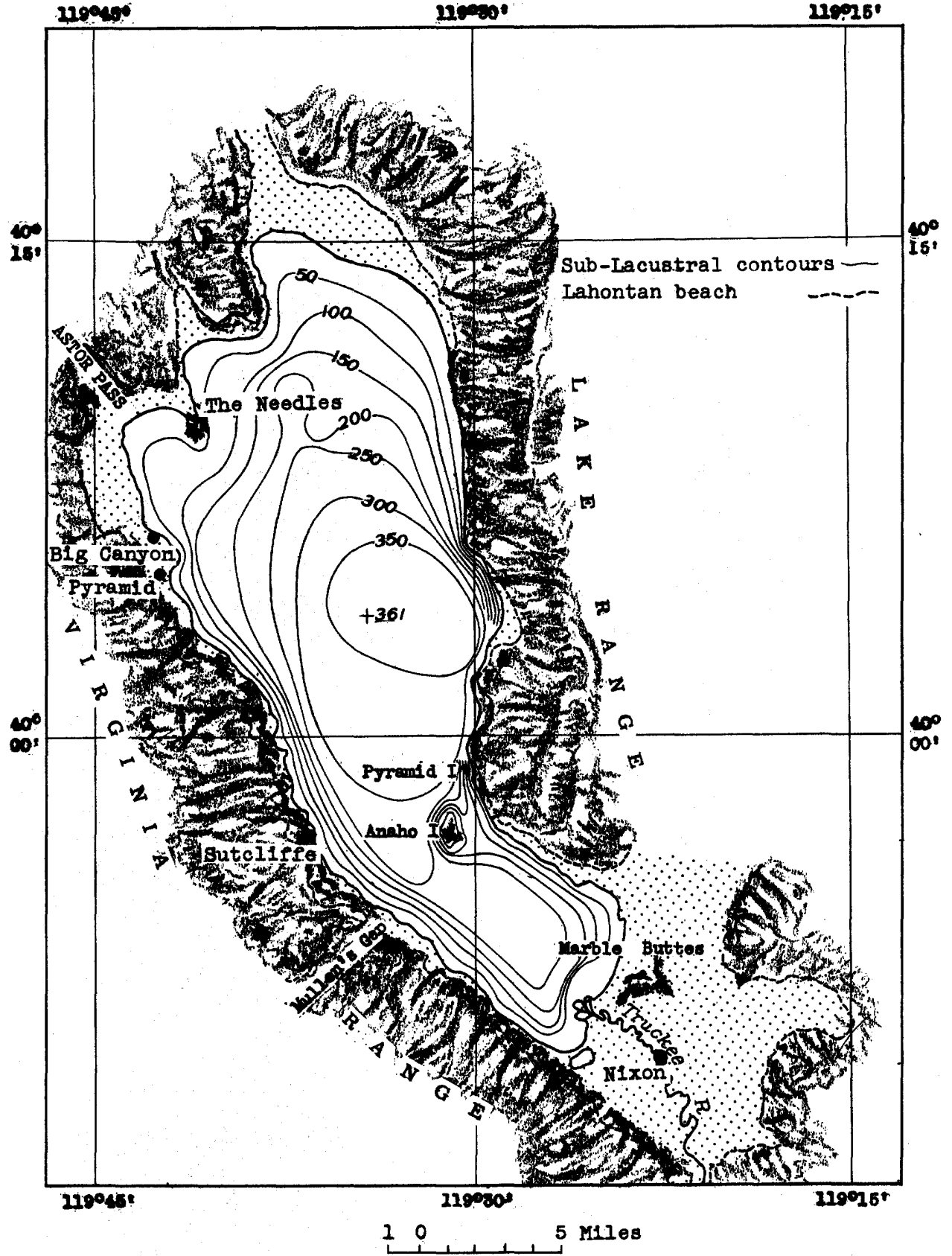

Figure 4. -- Map of Pyramid Lake, Nev. (after Russell, I. C. 1885). 
ranch near the town of Pyramid produces a small amount of hay. Along the northwest ahore of the lake is a narrow band of vegetation averaging perhaps 100 feet wide and about $1 \mathrm{mlle}$ long. At the north end of the lake, east of The Needles, a larger area of about 2 square miles is rather sparsely covered with phreatophytes. At an estimated consumptive-use rate of 1.0 acre-foot of water per acre, the total water consumed probably does not exceed 1,300 acre-feet per year. As previously mentioned, the east shore could not be inspected, but the aerial reconnalssance revealed that there is very little marginal vegetation along the east shore or in the draws leading up into the mountains.

The volume of ground-water inflow cannot be precisely evaluated, but it is believed small. Movement of ground water through the finegrained Lake Lahontan beds is undoubtedly small, but the possibility of substantial ground-water flow in the Truckee River channel should be invest1gated. Pumping tests to determine the permeability of these deposits would be required. Based on this information and on observations of hydraulic gradient in test wells, the volume of ground-water flow in the Truckee River channel could be computed with acceptable accuracy. The field coefficient of permeability, as defined by Meinzer (1949, p. 454), is conservátively estima ted to be 5,000 gallons per day. The hydraulic gradient is assumed to paraliel the stream bed, which has a gradient of about 8 feet per mile. From a topographic map the average width of the channel is estimated to be 1 mile. The thickness is assumed to be 100 feet on the basis of a rather common thi ckness of this magnitude in many western areas. Based on these data, flow through the aquifer is computed as 4,400 acre-feet per year.

An approximate water budget for Pyramid Lake can be calculated. Evaporation is estimated by Harding (1935, p. 508) to be about 4 feet per year. The surface area of the lake is approximately 120,000 acres, so that annual evaporation is 480,000 acre-feet. There is no surface outflow from the lake and no evidence of deep-seepage losses. Annual surface Inflow from Truckee River averages 36,000 acre-feet per year and from the remalnder of the Pyramid Lake Basin about 4,000 acre-feet. Rainfall on the lake averages about 7 inches per year, or 70,000 acre-feet. Total surface inflow is approximately 110,000 acre-feet per year. If it is assumed that infrequent short periods of storm runoff may be excluded from the computations, it is estimated that surface inflow can be measured within 10 percent, or 11,000 acre-feet, which is 2.3 percent of the annual evaporation. If the allowable error in measuring the difference between inflow and outflow (outflow from Pyramid Lake is zero) is to be not more than 5 percent of the evaporation, the maximum permissible error in measuring inflow to Pyramid Lake must not exceed 24,000 acre-feet. To meet this requirement, it is necessary that the error in measuring groundwater inflow not exceed 13,000 acre-feet. Meeting this requirement appears practicable in view of the magnitudes of the quantities involved.

The meteorological conditions at Pyramid Lake are complicated by its large size and by the surrounding terrain. It is evident that surface winds are affected by the topography. When the lake was visited on September 19 , 1949 , several residents of $\mathrm{N1x}$ xon at the south end of the lake agreed that westerly winds prevalled throughout the year; and the wind was observed to be westeriy on this day. A resident of sutcliffe, on the west side of the lake, stated that the wind blew in the direction of the long axis of the lake (northwestsoutheast) during the entire year, which is in agreement with the wind direction observed at this point on the day of the inspection trip. At the north end of Pyramid Iake near The Needles, gusts up to 20 miles per hour were observed several times, indicating the possibility of local thermal winds.

It appears reasonable to assume that local land and sea breezes develop during the night and day around a lake as large as Pyramid Lake. This would occur even if the surrounding terrain were flat. Drainage tongues from the adjacent mountains reinforce the land breeze. Local valley winds during the day reinforce the lake breeze, moving inshore and up the valleys. The wind structure over the lake, both day and night, therefore, consists of a series of tongues around the shore superimposed upon and confusing the general flow.

For the contemplated studies, it is required that the stream-line patterm of wind flow over the lake surface be known, and for Pyramid lake this information is lacking. A study of the local wind structure is needed; this would require the operation of a network of at least 8 or 10 anemometer stations for at least a year. Without such a study, the proper cholce of sites for the meteorologlcal Installations could not be made. Moreover, the size of the lake and the probable complexity of 1 ts wind structure make it likely that a larger number of meteorological installations will be needed than is now planned for the pliot lake.

Direct evidence is lacking as to the maximum height of waves to be expected. According to sverdrup (1945, p. 1055), the maximum probable wave helght, in feet, in the ocean for very strong winds is $1.5 \sqrt{\mathrm{F}}$, when $F$ is the fetch in nautical miles. For a fetch of I8 nautical miles, the maximum height of waves to be expected is $6 \frac{2}{2}$ feet. Based on his observations in 1882 , Russell (1885, p. 62) wrote "Even in summer the gales rise suddenly, without warning, and sweep down upon the lake with the fury of a tempest. Sometimes within a few moments the lake is changed from a placid mirror to a sea of frothing billows that break on the shore in long lines of foam. The suddenness with which the wind changes, and the bleak, inhospitable character of the shores, make the navigation of this lake somewhat dangerous, even to experienced boatmen."

A detailed hydrographic survey of Pyramid Lake would be required. The only hydrographic map avaliable is that prepared by Russell (1885, pl. 9) on the basis of soundings made in 1882. The maximum depth of water found at that time was 361 feet at a point approximately 8 miles northwest of Anaho Island. Based on area-capacity curves prepared from Russell's data, Pyramid Lake now contalns approximately $20,000,000$ acre-feet of water; its surface area is approximately 120,000 acres (187 square miles); and its average depth 167 feet. 


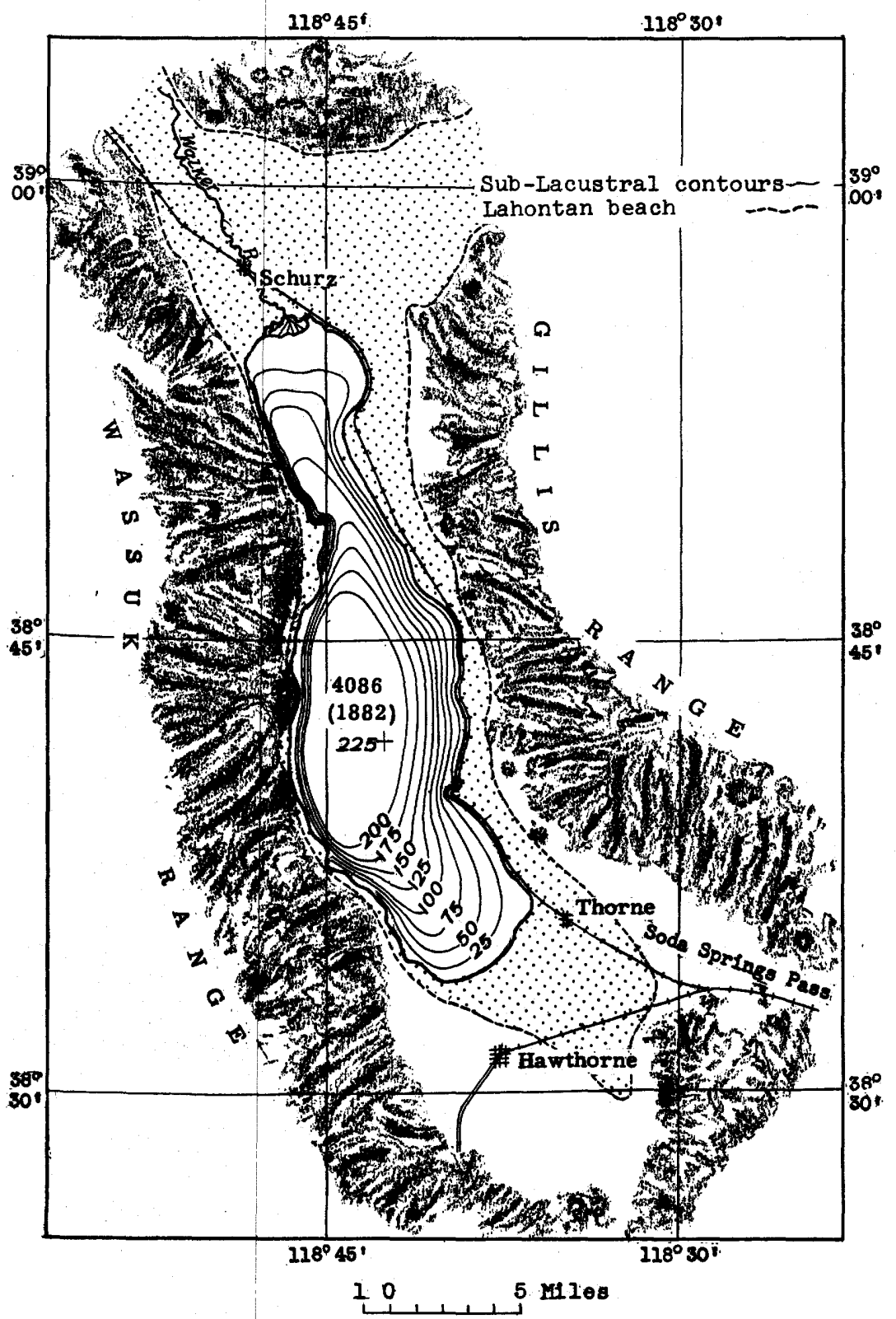

Figure 5. -Map of Walker Lake, Nev. (after Russell; I. C., 1885). 
As a pllot lake for the water-loss studies, Pyramid Lake has both its advantages and disadvantages. Its greatest advantage is that the water budget can presumably be determined with the required degree of accuracy. The complexity of the wind structure would require further investigation; but probably the most serfous disadvantage is the large size of the lake. size, by 1 tself, if above the required minimum, cannot be considered a disadvantage on theoretical grounds. From a practical viewpoint, however, the large olze of Pyramid Lake poses many problems, of which one of the more $1 \mathrm{~m}-$ portant is the increased instrumentation required. The hydrographic survey would not be a simple task; the inaccessiblilty of the eastern shore complicates the transportation problem. These apparent objections are not insurmountable, however, and Pyramid Lake has much to recommend 1t for a study of this nature.

\section{WAIKER LAKE, NEVADA}

Walker Lake is located in Mineral County in western Nevada. It lies in one of the several closed basins that are remnants of Lake Lahontan, a Plelstocene lake of the Great Basin. Walker Lake was approximately 23 miles long and varied from $1 \frac{1}{2}$ to $7 \mathrm{mlles}$ in width when surveyed in 1909. The lake is now about 75 feet lower than in 1909, and the area has decreased conslderably, particularly at the north end where the slope is flat. (See fig. 5, p. 13.)

Area-capacity curves for Walker Lake have been prepared (see flg. 6) based on Russell's hydrographlc survey (1885, pl. 15) of the lake in 1882. The surface area in September 1949 was approximately 44,000 acres and the contents $4,000,000$ acre-feet. Maxi mum depth at this time was approximately 140 feet.

The accompanying graph (f1g. 7) shows how lake levels have declined in recent years. The data prior to 1927 a re from a compliation by Antevs (1938, p. 40). Following a sharp rise in the 1860s, the lake level declined only 14 feet between 1868 and 1919. Increasing use of water for irrigation during the last 30 years has greatly diminished the inflow from Walker River, and the decline in lake level has been greatly accelerated. Only in 1938 did a substantial rise occur. The elovation of the water surface on september 30, 1949 , was $4,002.8$ feet.

Walker Lake lies between the Wasuk Range whlch rises more than 11,000 feet on the west and southwest and the Gillis Range which rises 7,500 feet on the east. Slopes on the west side of the lake are much steeper than those on the east.

The surface supply of Walker Iake is derlved princlpally from Walker River. A number of ephemeral streams drain directly into Walker Lake, mostly on the east slope of the Wassuk Range.

An aerlal reconnalssance of the lake on September 14, 1949, revealed w1 th great clarity the areas in which ground water is a vallable for plant growth. Only a few green patches were seen along the eastern shore and very little green vegetation in the many small draws extending into the olilis Range to the

Surface area, in thousands of acres

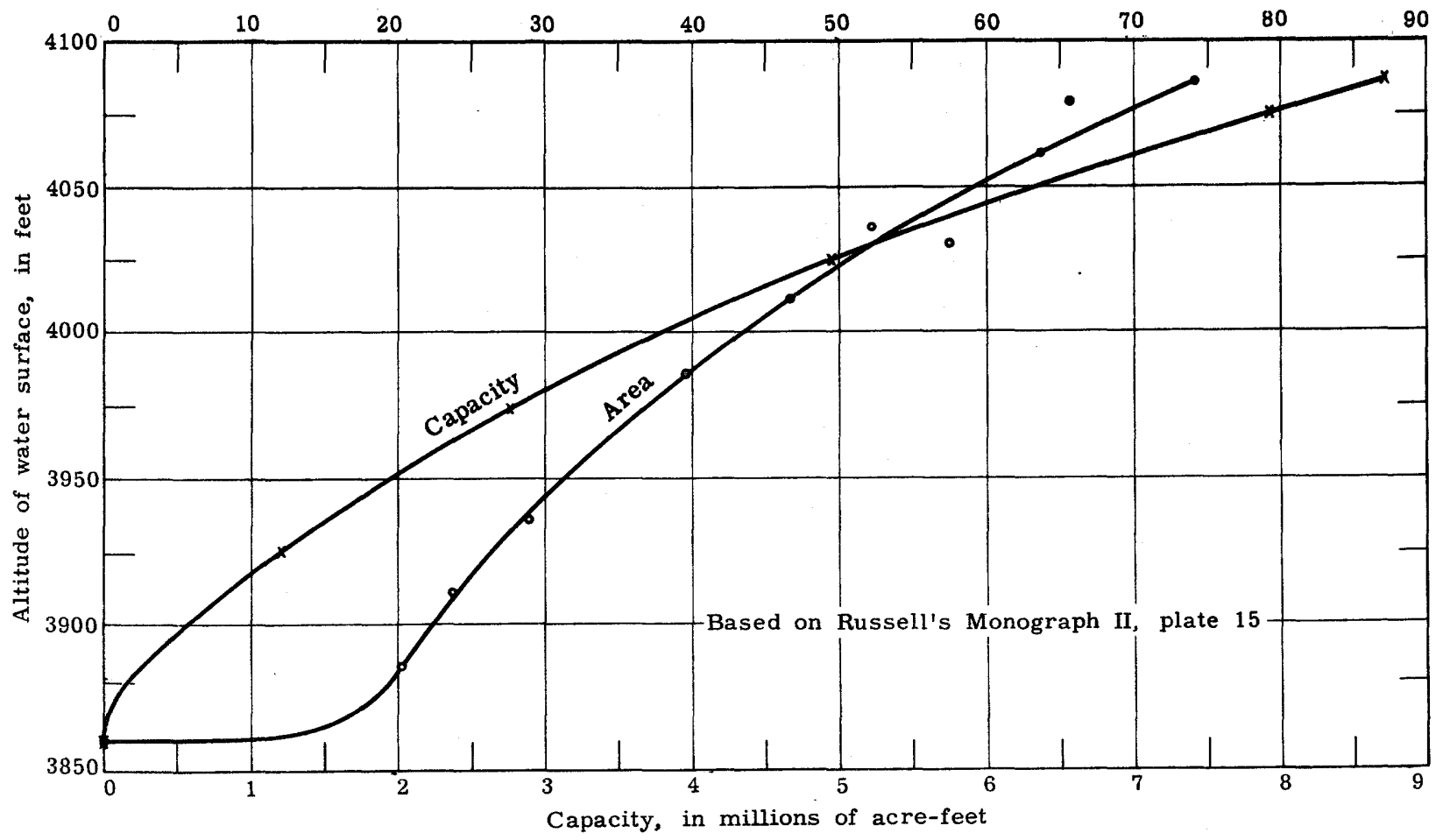

Figure 6.-- Graph showing area and capacity curves for Walker Lake, Nev. 


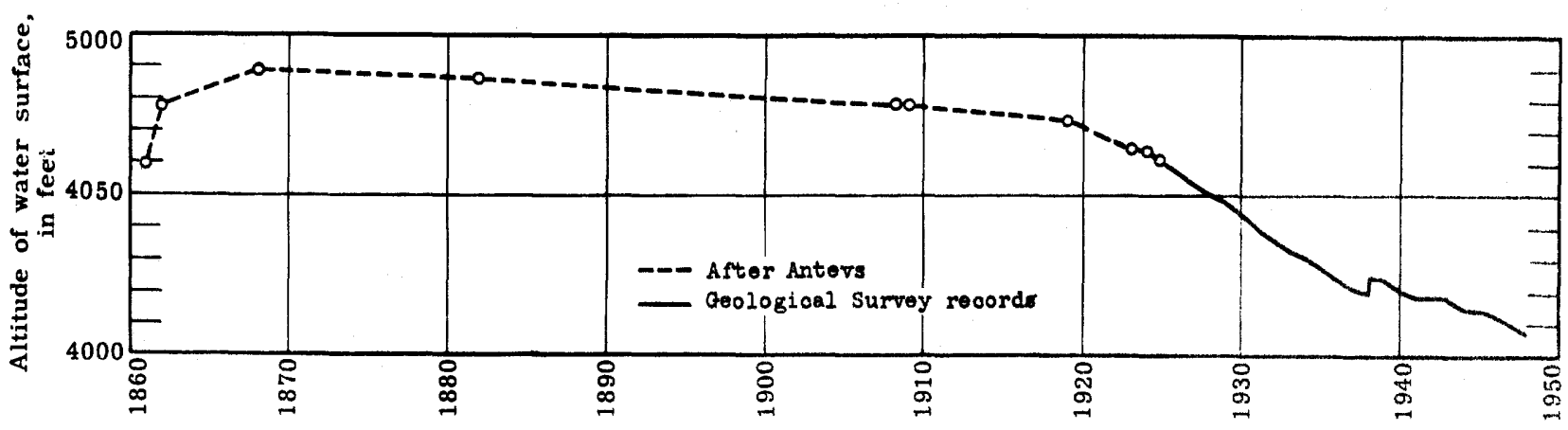

Figure 7.-- Graph showing stages of Walker Lake, Nev.

east. Fairly extensive areas of plant growth border the south end of the lake. The draws on the west side of the lake extending up into the Wassuk Range have green vegetation in their upper reaches. At the north end of the lake the Walker River delta is marked by extensive areas of phreatophytes, presumably supplied from underflow of Walker River and from subsurface return flow from irrigation.

An approximate annual water budget for Walker Lake has been prepared. Based on the hydrograph of lake levels (see fig. 7) and the area-capacity curves (see fig. 6) based on Russell's survey, the average annual change in contents for October 1, 1923, to September 30, 1949, was 133,000 acre-feet. Th1 s may be in error, for the area-capac1ty curves based on Russeli's survey are questionable. When the Hawthorne quadrangle was mapped by the Geologlcal Survey, the water surface elevation of Walker lake was found to be 4,078 feot (adjustment of 1912). The surface area of the lake as planimetered from this map is 66,000 acres. Based on Russell's hydrographlc survey, the surface area at an elevation of 4,078 feet is 72,000 acres. Harding (1935, p. 508) used a figure of about 90 . square miles, or 57,600 . acres, at a stage of 4,030 feet. The area from Russell's curve corresponding to an elevation of 4,030 feet is 52,000 acres. If Walker Lake is to be used for water-loss studies, a hydrographic survey will be required, but for the purposes of this report, the area-capacity curves based on Russell's survey a re assumed to be correct.

Average annual runoff of Walker River at Schurz for the water years 1924-33 (after storage in Topaz and Bridgeport Reservolrs began) was 24,300 acre-feet. This is believed to be of the approximate general order of magnitude for present-day conditions, although possibly less than during the period 1934-49. Flow of West walker River near Coleville, Calif., which is believed to be reasonably representative of natural runoff in this region, during the water years 1924-33 averaged about 70 percent of flow during the years 1934-49. It is difficult to tistimate discharge of Walker River into Walker Lake after 1933, because records of flow at Schurz are lacking. The capacity of Topaz Reservoir was increased in 1937 and the area of irrigated land has been increased since the 1924-33 period, thus further complicating the situat on. In the absence of accurate discharge data for Walker River for the entire 1924-49 period, however, average inflow is assumed to be 24,300 acre- feet, on the besis of records at schurz for the water years 1924-33.

Other inflow 1 tems in the water budget include the flow of ephemeral streams, precipitation on the lake surface, and ground-water inflow. A number of ephemerc s streams discharge directly into Walker Lake, mostly on the east slope of the Wassuk Range; their total contribution to Walker Lake is small, probably averaging less than 8,000 acre-feet per year, based on estimated runoff of 0.25 inch or less from an area of approximately 600 square miles. Average annual rainfall on the lake, taken as the mean of the weather Bureau records at Schurz and Thorne, is 4.4 inches. The average surface area of the lake during the period 1924-49 was 55,000 acres; therefore, average rainfall on the lake surface was 20,000 acre-feet. The ground-water Inflow to the lake can be approximated within reasonable $11 \mathrm{mits}$. Most ground-water inflow is supplied by Walker RIver. The Walker River flood plain below Schurz is 1 to 4 mlles wide. Assuming a width of $4 \mathrm{mlles}$, a hydraulic gradient of 8 feet per m1le, a thickness of 100 feet, and a permeabl 11 ty of 1,000 gallons per day (Meinzer's units), ground-water inflow is 3,600 acre-feet per year. The assumed permeablilty of 1,000 gallons per day is belleved to be a conservative upper IImit for the Lake Lahontan and Walker River fine sediments.

To summarize, an approximate annual water budget is as follows:

Quantity

(acre-feet)

Walker River inflow

Runoff of ephemeral streams

Precipitation on lake surface

Ground-water inflow

Decrease in contents of Walker Lake

24,300

8,000

20,000

3,600

133,000

Total

188,900

On this basis average annual evaporation is computed to be 3.4 feet, which appears to be somewhat low. The estimates a re admittediy only approximate, and have been prepared orly to illustrate the relative magnitudes of the quantities involved. The annual decrease in contents is by far the largest item, and can be measured with sufficient precision. Of the other items, ground-water inflow is probably the most difficult to determine accurately; but an error of a hundred percent in measuring this item would be almost insigniflcant 
compared with evaporation. It therefore appears that the water budget for Walker Lake can be determined with the required acouraoy.

Meteorological conditions at Walker Lake were not investigeted. The mountain ranges on each side of the lake undoubtedly complicate the wind-flow pattern. Data on prevalling surface winds at Walker Lake are not avallable, but because of the mountain ranges on each side the general flow is probably parallel to the long axis of the lake except where locally modified by valley breezes on summer days and air drainage at night. The effect on the general wind flow of turbulence induced by the mountain ranges on each side of the lake is not known.

It appears that a satisfactory water budget can be obtained at Walker Lake. The decision to reject it as a site for the water-loss studies was based primarily on its undesirable shape and its complicated wind structure resulting from the nearby mountain ranges. No field investigation was made to provide an estimate of the cost of elther the streamgaging stations required or the necessary ground-water studies. Al though unsultable for the present study, Walker Lake may prove satisfactory for studies to which its elongated shape and complicated wind structure are of no consequence.

\section{BYNOM RESERVOIR, MONTANA}

Bynum Reservo1r in north-central Montana is an 1 rrigation reservolr supplied from Teton River and formed by a dam on Alkall Creek in T. 26 N., R. 6 W., 4 miles west of the town of Bynum, in Teton county. (See fig. Q.) It is owned by the Teton Cooperative Reservolr Co. The reservoir is roughly circular in shape. Its surface area $a . s$ measured on the best available map is 4,120 acres (Congress, 1932, map 12) and 1 ts average depth at full pool 1 s approximately 20 feet. It holds 85,000 acrefeet of water at full pool elevation of 4,175 feet and 500 acre-feet at 4,130 feet. The reservolr stage on September 24, 1949, was estimated to be 10 feet lower than normal high water as shown by well-defined marks on the intake tower. Annual diversions to Bynum Reservolr average 25,000 acre-feet.

Bullt in 1910 and enlarged in 1926, the earth-fill dam, including the dike, is approximately $1 \mathrm{mile}$ long, and 1 ts maximum helght is 60 feet. The wes ternmost quarter mile of the dike is faced with concrete on the upstream side. The concrete outlet tunnel discharges into the distribution canal which is lined with concrete for a distance of 150 feet below the dam. A gated wasteway from the canal discharges into a small natural channel bolow the dam.

Both the dam and the reservoir are underlain by the lower part of the Two Medicine formation, which consists of coarse-bedded gray, greenish-gray, red, and yellowish-brown jointed shale interbedded wi th many irregular and extremely lenticular sandstone beds. A few siltstone beds and one 6 -inch bed of sandy, orange-brown bentonite were observed. In this locality the shales break down into tough, highly plastic clays upon remoulding. The sands tones are brownish-gray in color and have calcareous cement. Most of them are thinly

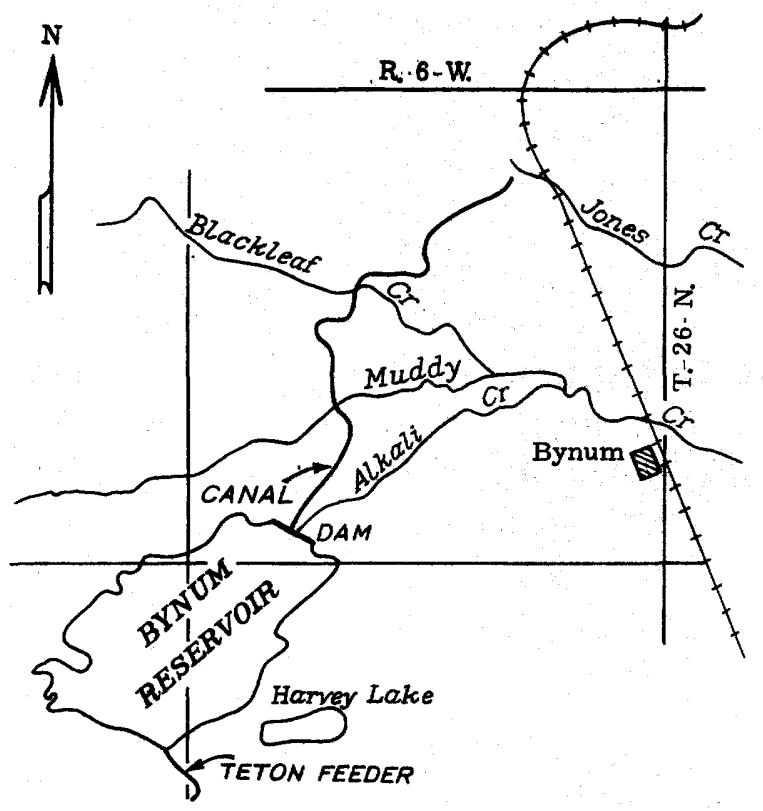

Figure 8. - Map of Bynum Reservoir, Mont.

and irregularly bedied, but a few a re massive. Cross bedding is common. Thickness and composition vary greatly. Some beds are made up of coarse uniform grains, others of grains wellgraded from coorse to fine, and still others of grains so fine as to be barely discernible with the naked eye. The variations in texture indicate that permeability probably varies greatly with the individual bed.

The regional dip of the Two Medicine formation is about 120 feet per mile southwestward with a strike of about N. $38^{\circ} \mathrm{W}$. (Dobbin and Eramann, 1946). In the flela, a local dip of $4^{\circ} \mathrm{SW}$. was measured about 100 feet below the downstream toe of the dam, 0.23 mile from 1 ts north end. Strike of these beds was N. $677^{\circ} \mathrm{W}$. On the south shore of the lake about 0.25 mile from the dam, exposed sandstones dip $5^{\circ} \mathrm{SW}$. and strike N. $40^{\circ} \mathrm{W}$.

Three joint systems are present in the sandstone beds. One set is parallel to the bedding. A second system, very regularly developed at intervals of 0.5 to 3.0 feet, aips $85^{\circ} \mathrm{N}$. w1 th strikes ranging from N. $78^{\circ} \mathrm{E}$. to N. $85^{\circ} \mathrm{E}$ : A third set, roughly perpendicular to the second, is poorly developed and many joints deviate from the average a few degrees to 30 degrees. AlI the foints are open on the surface from $1 / 16$ inch to a maximum of $1 / 2$ inch. The dip is vertical.

No faults have been recogni zed in the immediate vicinity of the reservoir.

Swamp grass and efflorescent salts along the downstream toe indicate that water seeps under the dam almost its entire length. There are a number of small flowing seeps, and most of the ground in the area below the dam is soggy. The discharge of one seep was estimated to be 0.04 second-foot on September 24, 1949, and the leakage through the dam around the outlet tunnel was estimated to be 0.5 second-foot. 
Nearly all of the seopage is colleoted in the wasteway, and a point 300 feet below the dam, the flow was estimated to be from 1 to $a$ second-feet.

Figure $\theta$ is a sketch showling seopage areas below the dam and a cross section through the dam. Although water seepling from the reservolr along the bedding planes in the sandstone must travel up dip, the static head is sufficiently high to produce substantial out.flow below the dam.

Seepage when the reservolr is full is undoubtedly greater than that observed on September 24,1949 , when the reservolr was only partly full due to irrigation witharawals. At full pool the water seeping below the dam is under greater head, and the cross-sectional area is also increased. It does not appear unreasonable to suppose that seepage may then amount to 5 second-feet.

The possiblilty of deep seepage, or leakage through the bottom of the reservolr that might not reach the ground surface for a considerable distance below the dam, is considered remote because of the regional southwesterly dip of the Two Medicine formation and the relatively impervious character of the sediments at the bottom of the reservolr. Samples of the sediments that were deposited when the reservolr was at a higher stage and that are exposed along the shores were found to be composed pre-

\section{dominantly of clay and silt.}

Bynum Reservolr is supplied partly from Toton River. Water $1 \mathrm{~s}$ conveyed by canal from Teton River to a point in the Alkal1 Creok basin, from whence $1 t$ flows down a na tural atream channel to the reservolr. A gravel delt approximately 600 feet w1de and $\mathbf{a}, 000$ feet long has been formed where the stream debouches from the hills and flows into the reservolr. There was no evidence of surface flow at the delta at the time of the reconnalasance. A fow small pools of standing water were observied near the edges of the delta. The bottoms of some of the pools were silted.

At a point approximately 2,000 feot upstream from the shore of the lake the stream channel narrows to 200 feet in width. Here a small stream with a flow of from 1 to 2 second-feet disappeared into the gravel of the main channel and was not observed to reappear on the surface anywhere in the delta.

The stream was followed for a mile upstream from this point. Many side gullies were observed, and the sparsely covered hillsides show evidence of heavy overland flow and erosion. The nearest point to the lake at which it would be practicable to obtain a record of flow in the channel is approximately a mile above the mouth, where the stream has been cut down to the underlying sands tone. Although hea vy rains are infrequent, unmeasured inflow

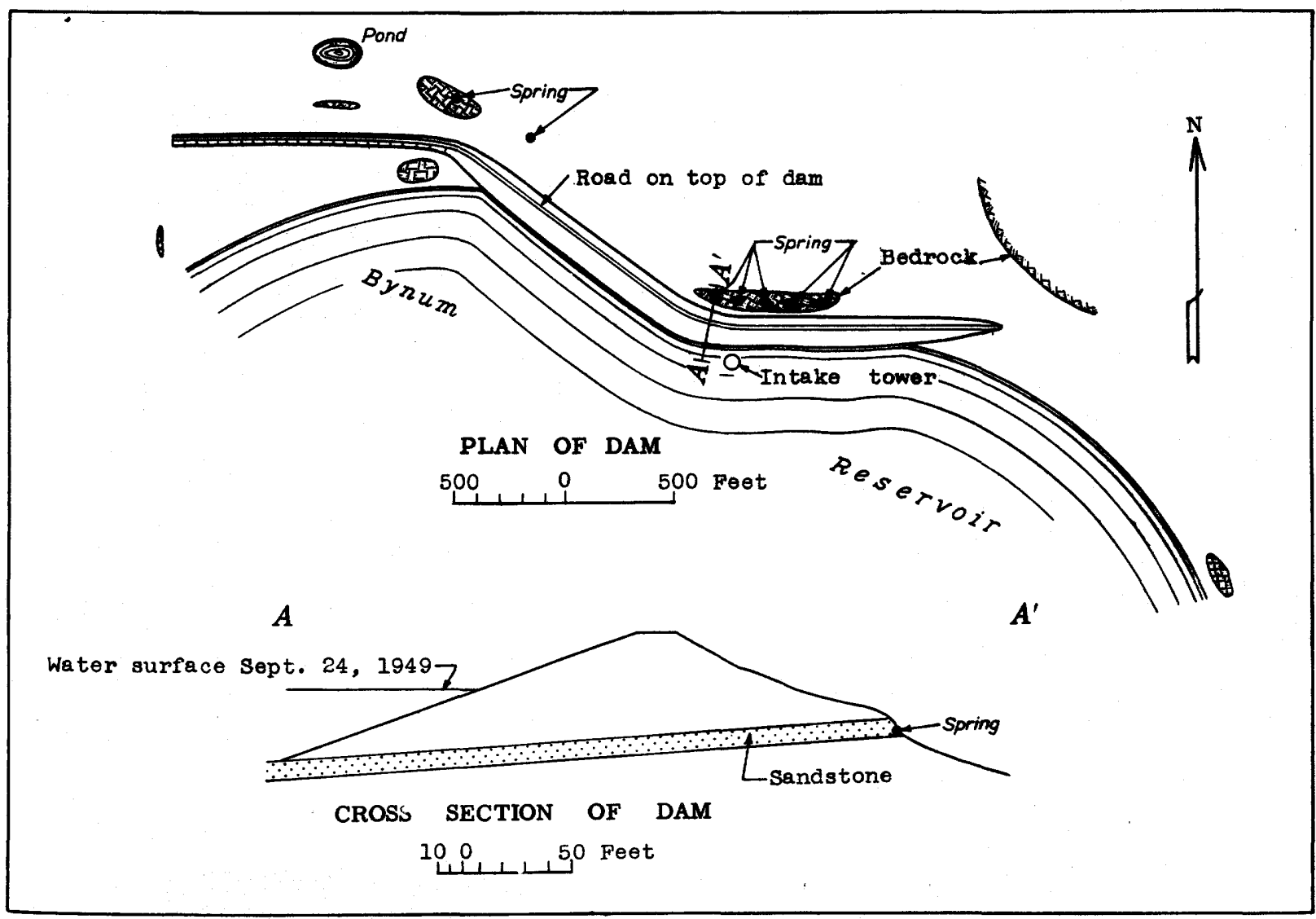

Figure 9. -- Sketch showing seepage springs below Bynum Dam, Mont. 
between this point and the reservolr might be of considerable magnitude.

Harvey Lake is a small irrigation reservolr located southeast of Bynum Reservolr (see flg. 8) and is supplied from the Teton River. Its capac1ty is about 3,000 acre-feet (Congress, $1932, p .90)$. At 1 ts nearest polnt Harvey lake is approximately 1,000 feet from Bynum Reservolr. Its water-surface elevation was estimated to be 20 to 30 feet higher than that of Bynum Reservoir. A dike has been constructed at the west end of Harvey Iake to prevent outflow to Bynum Reservolr. Alkall and swamp grass were observed in the 300-foot-wide connecting valley, indicating that there is subsurface flow from Harvey Lake to Bynum Reservolr.

On the northwest side of Bynum Reservolr well-defined drainage channels are lacking. There is evidence that, in this area, during heavy rains there may be substantial overland flow which would be difficult, if not impossible, to measure accurately. No a ttempt has been made to evaluate the volume or frequency of such flows.

Annual evaporation from Bynum Reservoir is approximately 33 inches, on the basis of an analysis of avaliable records of evaporation from pans. Of this amount about 9 inches evaporates during the months from April to June, the period of maximum inflow, and about 12 inches during the months of July and August, the period of maximum outflow.

The annual water budget cannot be accurately determined because of incomplete information on surface-water inflow and outflow and because of the total lack of data on magnitude of ground-water flow. Neglecting ground-water flow, the annual water budget may be approximated as follows:

Quant1ty

(acre-feet)

Inflow:

Diversions into Bynum Reservolr

25,000

Surface inflow from Alkali

Creek basin

Rainfall on reservolr surface

$$
\begin{array}{r}
2,000 \\
5,600 \\
\hline 32,600
\end{array}
$$

Outflow:

\section{Evaporation}

Reservoir releases (by difference)

11,000

21,600

It must again be emphasized that ground-water inflow, which may be an item of considerable magnitude, has not been included. Ground-water outflow of necessity has been included in the amount shown for reservoir releases. This figure was obtained by subtracting the evaporation, which is the only loss that could be estimated, from the total of the estimated inflow items. If the inflow items and the reservoir releases could be measured within 5 percent, which could be attained only at considerable expense for stream-gaging installations and operations, the error in the difference, on an annual basis, would be 18 percent of the evaporation. This figure would be substantially increased if errors in measuring ground-water. flow should be included, which is necessary for a complete determination of the difference between inflow and outflow. It is probable that, with an extensive collecting system below the dam, most of the seepage through the dam could be collected and measured. The volumes of ground-water inflow entering the reservoir in the areas adjacent to the supply canals and in the Harvey Lake area are unknown.

Bynum Reservolr was considered unsultable for the water-loss studies primarily because of the uncertainties involved in measuring surface- and ground-water inflow and outflow. The rather. short season of high evaporation 1 s an undesirable but not disqualifylng feature. In many other respects, however, such as size, shape, and freedom from undesirable orographic effects, Bynum Reservoir meets the desired standards.

\section{LAKE FRANCES, MONTÁNA}

Lake Frances is an irrigation reservoir on a small tributary of Dry Fork Marias River in north-central Montana, in T. $29 \mathrm{~N}$., R. 5 W., in Pondera County. The town of Valier is on its north shore. The oval-shaped lake is approximately 4 miles long and $2 \frac{1}{8}$ miles wide. At full pool the water-surface elevation is 3,816 feet (mean sea level), the surface area is 5,536 acres, and contents are 112,000 acrefeet, according to J. A. Tidyman of The valier Company, Valier, Mont., which owns the reservoir.

The reservolr is supplied by a canal known as the C-3 Canal (see fig. 10) which conveys water diverted from Birch and Dupuyer Creeks. Inflow is greatest during the months of May and June. Tidyman estimates that 50,000 acrefeet passes through the reservoir annually. Storm munoff from the natural drainage basin of approximately 25 square miles occurs infrequently.

The main dam at the southeast end of the lake is constructed of earth, has a concrete core wall (Congress, 1932, p. 82), and is 700 feet long and 50 feet high. Dike No. 1 , on the northwest side of the lake, is 6,260 feet long and 20 feet high. Dike No. 2 on the northeast side of the lake is 725 feet long and 4 feet high.

The extreme southeast end of the reservolr and the dam site are underlain by the virgelle sandstone member of the Eagle sandstone, which consists of buff to grayish-buff, highly crossbedded sandstone. It is thinly laminated, finegrained, soft, and friable, with some calcareous cement. The remainder of the reservolr is underlain by the Two Medicine formation. Contact between the two formations is hidden by surficial deposits. The Two Medicine formation consists of poorly bedded, gray, greenish-gray, red, and yellow clay shales interbedded with irregular amounts of lenticular gray-to-buff sandstones and an occasional siltstone. It is not exposed in the immediate vicinity of the lake but can be seen in the valley of Dupuyer Creek.

In the vicinity of Lake Frances these beds dip gently northwestward at 75 to 80 feet per mile (Dobbin and Erdmann, 1946). The strike of the beds varies from N. $41^{\circ} \mathrm{E}$. to N. $33^{\circ} \mathrm{E}$. along the northern and eastern shores of the lake but changes gradually to nearly north on the south side of the lake. No faults have been recognized in this immediate vicinity. 
R. 6 W. $112^{\circ} 20^{\circ}$

$112^{\circ} 15^{\prime}$ R. 5 W.

R. 4 W.112 ${ }^{\circ} 10^{\circ}$

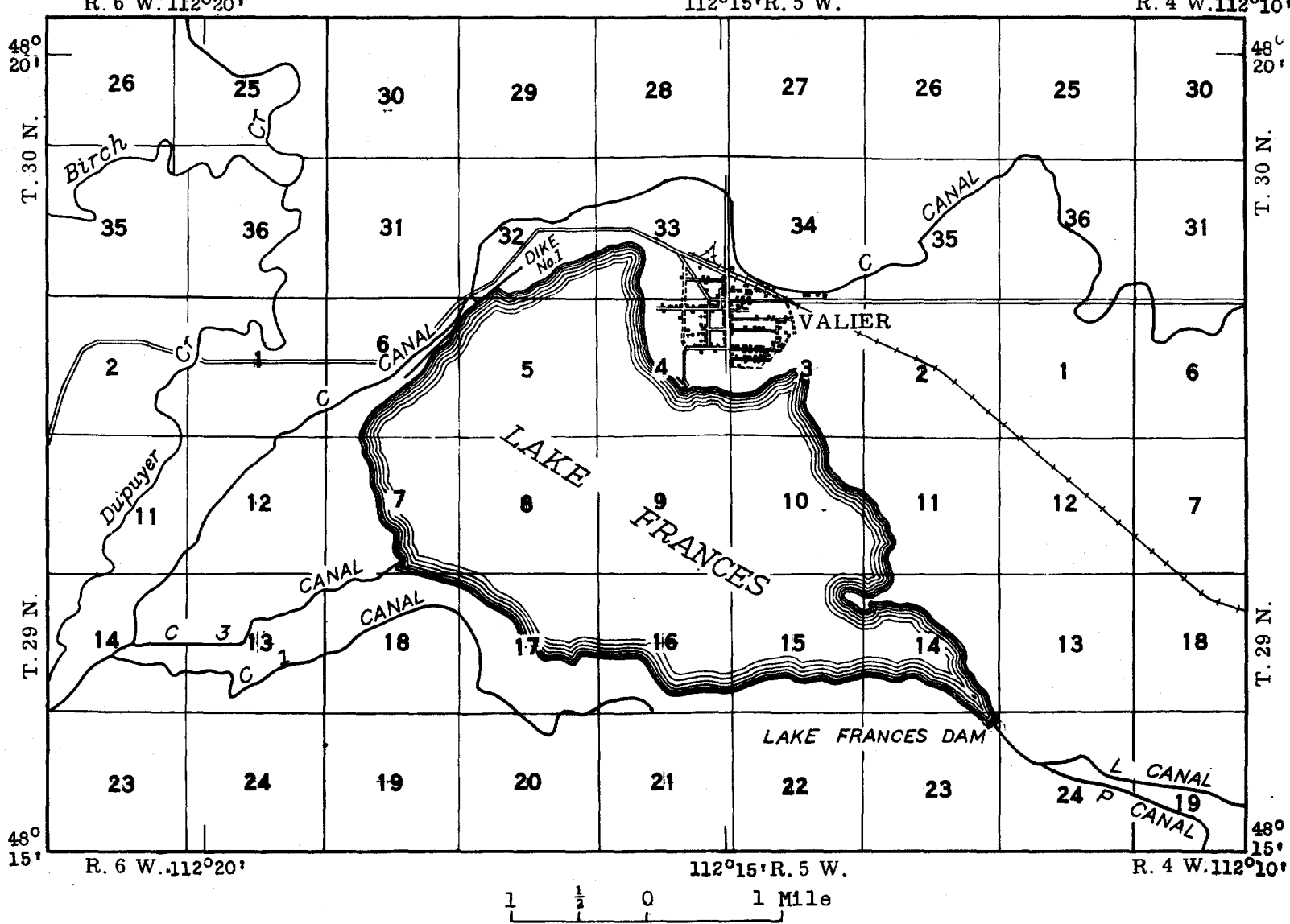

Figure 10. -- Map of Lake Frances, Mont.

Except for the previously mentioned small area at the lake outlet, bedrock is covered by an unknown thickness of glacial debris and alluvium throughout the lake basin and adjacent areas. Ilttle is known of the character of these surficial deposits because the land is farmed and no good exposures were found.

Most of the inflow to Lake Frances is conveyed by the $\mathrm{C}-3$ Canal which was inspected at the road crosing approximately half a mile above the lake. Its design capacity is 900 cublc feet per second, but on september 24,1949 , the flow was estimated to be 70 cubic feet per second. The camal banks at this point are of soll underlain by a comparatively impermeable gravel-clay mixture. Along a 300foot reach the canal had cut through this material, exposing from 0.5 to 3.0 feet of clean coarse highly permeable sandy gravels of fluvial origin. Water entering these gravels may be discharged into the lake. A precise determination of the amount of water reaching the lake as canal underflow would be difficult.

Annual inflow from the natural drainage basin of approximately 25 square miles is between 0.5 and 1.0 inch, according to Langbein (1949, pl. 1). Using the higher figure, annual inflow is approxima tely 1,300 acre-feet. Some storm munoff would be included in the measured flow of $\mathrm{C}-3$ Canal, but the determination of inflow from the area immediately adjacent to the lake might prove difficult.

It is probable that some return flow from irrigation may enter the reservoir along the southwest shore. According to Tidyman, an area of about 300 acres is irrigated. from the C-I Canal, usually only once each year. A total of 200 acre-feet of water is applied. The return flow. probably does not exceed 100 acre-feet.

Annual precipitation at valier, according to U. S. Wea ther Bureau records (Commerce, 1948 , p. 254), averages 12.65 inches, which amounts to 5,800 acre-feet at full-reservolr level. Precipitation durlng May and June, the two wettest months, averages 1.83 and 3.00 inches, respectively.

Surface outflow from the lake is discharged through the dam into a canal. Because of $a$ diversion structure half a mile below the dam, precise measurements of outflow might prove difflcult. It is also possible to release water from Lake Frances into the $C$ Canal at a point near the northeast end of dike No. 1. The floor of the outlet structure is at 3,800 feet elevation, or 16 feet below full-pool elevation. 
Subsurface outflow from the reservolin $1 \mathrm{~s}$ apparently reotricted to the area near the main dam and to the area near dike No. 1. A collecting gallery intercepts part of the seepage through the dam. This flow, about 0.5 cublc foot per second, is pumped to the Conrad municipal water-supply system. Near the dam, Virgelle sandstone is exposed along the shore on both sldes of the lake for a distance of about 2,000 feet above the dam. It is also exposed along the Dry Fork Marlas River tributary below the dam in sec. $24, T .29$ N., R. $5 \mathrm{~W}$. The beds dip in a northwesterly direction at low angles. The following determinations were made:

No. Location Strike Dip

1 Lake shore, SWt SW sec. 14 , T. $25 \mathrm{~N} ., \mathrm{R} .5 \mathrm{~W}$.

2 Dry Fork Marias River tributary, SE $\frac{1}{4} N^{\frac{1}{4}}$ sec. 24 , T. 29 N., R. 5 W.

3 Dry Fork Marlas River tributary, SE $N W \frac{1}{4}$ sec. 24, T. 29 N., R. 5 W. 4 Road cut, Et corner sec. 23 , T. 29 N., R. 5 W.
N. $44^{\circ}$ W. $6^{\circ}$ SW.

N. $58^{\circ} \mathrm{E} \cdot 5^{\circ} \mathrm{NW}$.

N. $75^{\circ}$ E. $30 \mathrm{NW}$.

N. $30^{\circ} \mathrm{W} .70 \mathrm{SW}$.

Determinations 1 and 4 are probably on cross laminations, but determinations 2 and 3 agree roughly with the regional dip and are believed to represent true bedding of the sandstone. Permeability normal to the bedding of the sandstone is probably comparatively low, but permeablilty along the bedding and crossbedding surfaces is fal rly high. This is demonstrated by a serles of seeps that discharge along the north wall of the valley (called the $P$ Canal) and that are supplied from the I Canal. The seepage water is under a head of about 14 feet and travels along paths varying from 25 to 200 feet in length. Discharge is entirely along the bedding and cross-bedding surfaces. The seepage in this area on September 24,1949 , was estima ted to be about 3 gallons per minute. Wi thout doubt seepage is also taking place through these sandstones a round both abutments of the dam. A well into rock at the farmhouse near the nor thwest corner of sec. $24, T .29$ N., R. 5 W., intercepts part of this flow. The water level in this well is reported to fluctuate with the stage of the reservolr. The quantity of seepage water may not be large, but it would be difficult to measure accurately.

There is considerable seepage along dike No. 1. This seepage water, together with seepage from the C Canal, collects in a pond at the $s \frac{3}{4}$ corner sec. 31 , T. 30 N., R. 5 W. Seepage appears to be confined to the contact between the dike and its foundation and to the lower part of the dike. It might be possible to separate the amount of seepage through the dam from amount of the seepage through the canal banks by measurements of the seepage when the canal flow is zero.

The remainder of the lake basin appears to be comparatively watertight despite the fact that it is floored by strata of the Two Medicine formation that contain many permeable sandstone members. Seepage is prevented by a blanket of surficial deposits, no doubt assisted to some extent by silting of the reservoir. The impermeability of the soll and underlying surficial deposits is demonstrated

by the fact that on September 24, 1849, water Wa sanding in a pond about a quarter of a mile east of the lake, in the sW' sec. 13, T. 28 N., R. 5 W., at an elevation approximately 35 feet higher than maximum lake level. Th1s pond was formed in June 1948 by surface munoff following unusually heavy ralns. Subsequent loss of water has been at a sufflclently low rate to be accounted for by evaporation, Indicating that seepage losses have been negliglble.

Annual evaporation from Lake Frances as based on an analysis of a vallable records of evaporation from pans is about 33 inches. At full pool, annual evaporation is 15,200 acre-feet.

An approximate annual water budget, assuming Tidyman's estimate of 50,000 acre-feet passing through the reservoir to be outflow, is as follows:

Quantity

Outflow :

Reservoir releases

(a cre-feet)

Evaporation

Seepage

Total outflow

$$
\begin{array}{r}
50,000 \\
15,200 \\
1,000 \\
\hline 66,200
\end{array}
$$

Inflow :

Rainfall on lake

Return flow from irrigation

c-3 Canal (by difference) Total inflow
5,800

100

60,300

66,200
The flgure for seepage loss is admittedly only a rough estimate and has been included only to indicate its approximate relative magnitude. The water budget indicates that inflow and outflow a re approximately four times as great as evaporation. If the measurement errors are considered to be normally distributed, and both inflow and outflow can be measured within 5 percent, the error in the difference between the two quanti ties $1 \mathrm{~s}$ about 4,000 acre-feet, or more than 25 percent of the annual evaporation.

The weter budget is further complicated by the configuration of the lake, which makes accurate determinations of mean stage somewhat difficult. The lower end of Lake Frances terminates in a rather narrow neck. The amplitudes of selches caused by the prevaling westerly winds are probably magnifled very much in the area near the dam. The assumption of a plane water surface cannot be made, and a network of precise stage gages would be required.

Meteorological conditions at Lake Frances appear to be favorable. The terrain is falriy flat except along the south shore where hills rise to a helght of 100 to 200 feet above the lake at a distance of a mile or so away. The wind structure apparently is not complicated by orographic effects. The prevailing winds are westerly. Summer humidity is low.

According to Tidyman, the lake is frozen from approximately December 5 to April 15 each year. Average January temperature is $16.6^{\circ} \mathrm{F}$ and a verage July temperature is $65.4^{\circ} \mathrm{F}$, according to Weather Bureau records (Agr1culture, 1941 , p. 917). Year-round observations of evaporation appear impractical. 
Lake Frances was rejected as a possible site for the water-loss studies because of the difflculty in obtaining a water budget of the required degree of accuracy. In many other respects, such as shape, size, depth, and freedom from orographic effects, the lake meets the requirements. The long perlod of ice cover in the winter is an undesirable but not disqualifying feature.

\section{IAKE ABERT, OREGON}

Lake Abert, oval-shaped and approximately $10 \mathrm{miles}$ long and 3 miles wide, is in a closed basin about $30 \mathrm{miles}$ north of the town of Lakeview in south-central oregon. Waring (1908, p. 38) made a geologic and hydrologic reconnalssance of the area in 1906 and determined the surface area of Lake Abert to be 60 square miles at that time. It has less than half that area at present and is much shallower than it used to be. No soundings were made on the day the reconnaissance was made, September 20, 1949, but the depth at the present time is reported by $\mathrm{R}$. A. Work (in a personal communication relaying information from Philip Smith) to be about 3 feet. The lake is shallower now than it has been for several years, al though it was lower in 1931 and 1934. Antevs (1938, p. 18) reported that it was dry in August 1924 except for a few small pools fed by springs and a small area on the east side supplied by Polson Creek. According to Waring (1908, p. 38), "The northerm end of the Abert Lake basin is so nearly level that it is sald that a strong south wind of ten forces the water back nearly 2 miles over the alkaline flat ***."

Lake Abert lies upon a huge block of Mlocene basalt that dips to the east. It is confined on 1 ts eastern side by the Abert Rim, a fault scarp that towers more than 2,000 feet above the lake and is sald to be one of the highest in the United States. Russell (1884, p. 447) described the Iake Abert fault as follows: "The grand cliffs that present an impassable barrier along the eastern shore of Abert Lake expose the broken edges of the strata on the heaved side of a fault; while the thrown side underlies the lake basin and forms the gently sloping western shore." A geologic section in an approximately east-west direction through Lake Abert is shown in figure 11 .

Accoraing to Waring (1908), "The basalt is a dark gray, fine-grained, rather vesicular rock, approximately parallel partings, usually at intervals of only a few feet, mark the division between successive flows, but in some places much thicker beds are exposed. Fissures nearly perpendicular to the parting planes break the basalt into blocks, which by transverse fracturing are reduced to smaller and smaller fragments, forming the characteristic talus slopes of the cliffs."

Chewaucan RIver enters the south end of Lake Abert, after flowing through the Chewaucan Marsh, and const1tutes almost the ent1re surface-water inflow into the lake. The average annual flnw of Chewaucan River above Conn ditch, near Paisley, Oreg., 1s approximately 85,000 acre-feet. However, not all the flow reaches Lake Abert as water is diverted from the Chewaucan River for Irrigation in the Palsley area; and although the return flow from Irrigation eventualiy finds 1 ts way through the Narrows to Lake Abert, the consumptive use may amount to more than half of the flow in some years. On the average, surface inflow to Lake Abert is roughly estimated to be 60,000 acre-feet, which is less than the evaporation from the lake. Flow of Chewaucan River into Lake Abert is not now measured and it is by no means certain that it can be measured within 5 percent, for the slope in the water surface in the reach below the dam and falls is small, and may be affected by strong winds or changes in lake levels. Runoff from spring rains in the area directly tributary to the lake would be difficult to measure accurately. No studies have been made of the frequency of these storms, but the total volume of runoff is small compared with the flow of Chewaucan River.

Many small fresh-water springs were seen on the east side of Lake Abert between the highway and the lake. The flow of some springs was so small as to produce only a marshy area having small pools of standing water. Many springs were discharging water directly to the lake. The volume of flow was small; discharge of most springs was estimeted to be less than 0.05 cubic foot per second. The temperature of the water in the seeps along the easterm shore was from $78^{\circ}$ to $79^{\circ} \mathrm{F}$. on september 20, 1949. The temperature of both the air and the water in the lake was $65^{\circ} \mathrm{F}$. at that time. The temperature of the water in a seep near the northeastern corner of the lake was also $65^{\circ} \mathrm{F}$.

At the north end of the lake are fairly extensive areas of marshland on which hay is grown. Irrigation water is supplied from numerous seeps. There is no simple way to measure the return flow from the irrigated areas. Waring (1908, p. 51) mentions a strong spring at the ranch house, but this spring was not looked for on the reconnalssance September 20, 1949.

Along the western shore the seepage area was estimated to be at least three times as great in extent as that along the eastern shore. The flow of several springs was estimated to be 0.5 cubic foot per second or more.

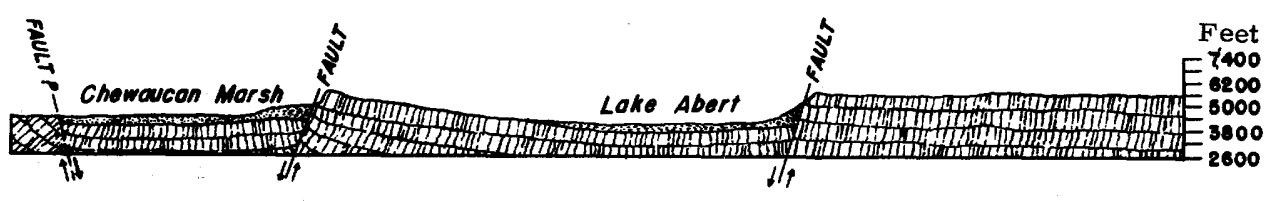

Figure 11.-- Cross section through Chewaucan Marsh and Lake Abert, Oreg.

(after Waring, 1908, plate 10). 
The seeps and eprings along the western shore according to Waring $(1808, \mathrm{p}$. 51), are ov1dently fed by waters that accumulate on the slopes between Lake Abert and Chewaucan Marsh, seep down the dip of the basalt, and reach the surface at the lake shore. (See $\mathrm{flg}_{\mathrm{g}}$. 11.) He did not mention the springs or seeps along the eastern shore, but it seems likely that they are supplied from the same source. As the water travels down dip under the lake 1t may be prevented from discharging into the lake bottom by the relatively Impervious sediments that have been deposited over the lake bed and can find its way to the surface only after it reaches the fault zone on the eastem side of the lake.

Annual evaporation from Lake Abert is estimated to be approximately 4 feet, based on an analysis of avallable records of evaporation from pans. of the 4-foot total, approximately 2.3 feet occurs during the 4-month period June to september.

An annual water budget for Lake Abert is difficult to estimate because of the lack of data but may be approximated as follows:

Quantity (acre-feet)

\section{Evaporation}

Inflow:

Surface water

Ground water (by difference)

77,000

60,000

17,000

Outflow is considered to be zero. Ground-water inflow was assumed to be that amount which, when added to the surface inflow, is required to maintain the lake at its present level. Both surface- and ground-water inflow are known to vary widely from year to year. The lake is now much smaller than in times past, indicating that inflow has generally been less than evaporation during recent years. On an annual basis, 5 percent of the estimated evaporation is 3,850 acre-feet--possible error in measuring ground-water inflow alone exceeds this amount. The possible error'in measuring surface-water inflow may also exceed 5 percent of the evaporation. The slope of the water surface of Chewaucan River in the reach upstream from the lake is flat and may be affected by the level of Lake Abert.

The volume of ground-water inflow during summer months, when flow of Chewaucan RIver 1s depleted by irrigation, may amount to a substantial portion of the total inflow. Obtaining continuous records of the flow of the many springs would be an expensive undertaking. The possibility of springs in the lake bed, although remote, cannot be ignored. The measurement of total inflow to lake Abert within the allowable limits of accuracy was deemed impracticable.

Annual precipltation at Valley Falls, at the southern end of Lake Abert, averages 11.10 inches. Rainfall during July, August, and September is light, but the remainder is welldistributed throughout the year. Humidity is normally low in central oregon during the summer, and westerly winds predominate. Average temperature at valley Falls is $30.4^{\circ} \mathrm{F}$. In January and $66.7^{\circ} \mathrm{F}$. in July (Agriculture, 1941, p. 1075 ).
The effect of topography upon meteorologl cal conditions at Lake Abert was not studied in deta11. The great fault scarp on the eastern side of the lake unquestionably affects the wind structure over the lake. Westerly winds predominate in the large scale ol roula ti on, but southerly surface winds prevall at the southern end of the lake at Valley Falls, as might be expected.

Because of the impracticability of determining the water budget with the required degree of accuracy, Lake Abert was considered unsuitable as a pilot lake for the water-loss study. Meteorological conditions are not favorable, and the lake is shallower than is desirabie, but the decision to reject Iake Abert was based upon the lack of an accurete water budget.

\section{BIG SAGE RESERVOIR, CALIFORNIA}

Big Sage Reservoir is an irrigation reservoir in northeastern California, $10 \mathrm{miles}$ northwest of Alturas in Modoc County. (See f1g. 12.) The reservolr is irregularly shaped, and when full covers an area of 5,570 acres and stores 77,000 acre-feet of water. It was constructed in 1921 by damming Rattlesnake Creok, a P1t River tributary that drains a broad, nearly flat, upland plateau about 5,000 feet above sea level. The drainage area is 107 square miles, according to Ingerson (1932).

The plateau on which Big Sage Reservolr lies is known as the Gardens (Russell, 1928, p. 400) or the Dev1ls Gardens (Zander, 1933, pp. 24$27)$. According to Russell, the Gardens plateau is about 2,000 square miles in area, and has a cap of smooth lava which he named the warner besalt. The basalt. is a vesicular volcanic flow of surprising extent and uni formi ty. It is approximately 30 feet thick at the south rim of the Gardens as exposed in the bluff north of the Alturas-Canby road (U. S. Highway 299). Near the south end of Goose Lake, at the east edge of the Gardens, it is at least 225 feet thick.

Russell's Warner besalt is underlain by his Cedarville series, a group of andesitic rocks about 7,500 feet thick. They are composed of tuff beds, agglomerate, and lava, all andesitic in character, w1 th about 5 percent of interbedded sedimentary rocks of nonvolcanic origin. Where observed in the bluffs north of Highway 299 near the dirt road leading to $B 1 \mathrm{~g}$ Sage Reservolr, the Warner basalt is underlain by a dense, white tuff bed whlch had the appearance of a "chalk rock". This tuff bed is very extensive, according to Russell.

Big Sage Dam was built in Rattlesnake Creek canyon, which has been eroded 40 to 50 feet below the surface of the Warner basalt. It is not known whether the stream had cut through the basalt into the tuffaceous beds beneath. Photographs made during the excavation for the dam suggest that the white tuff beds are exposed in the cut. T. R. Simpson of the California state Division of Water Resources, Sacramento, Calif., who was present when the excavation was made, states that the white tuff bed was exposed. The cut-off trench, which was excavated to a depth of 10 feet below the base of the dam, is therefore belleved to penetrate the fine-grained white tuff. 


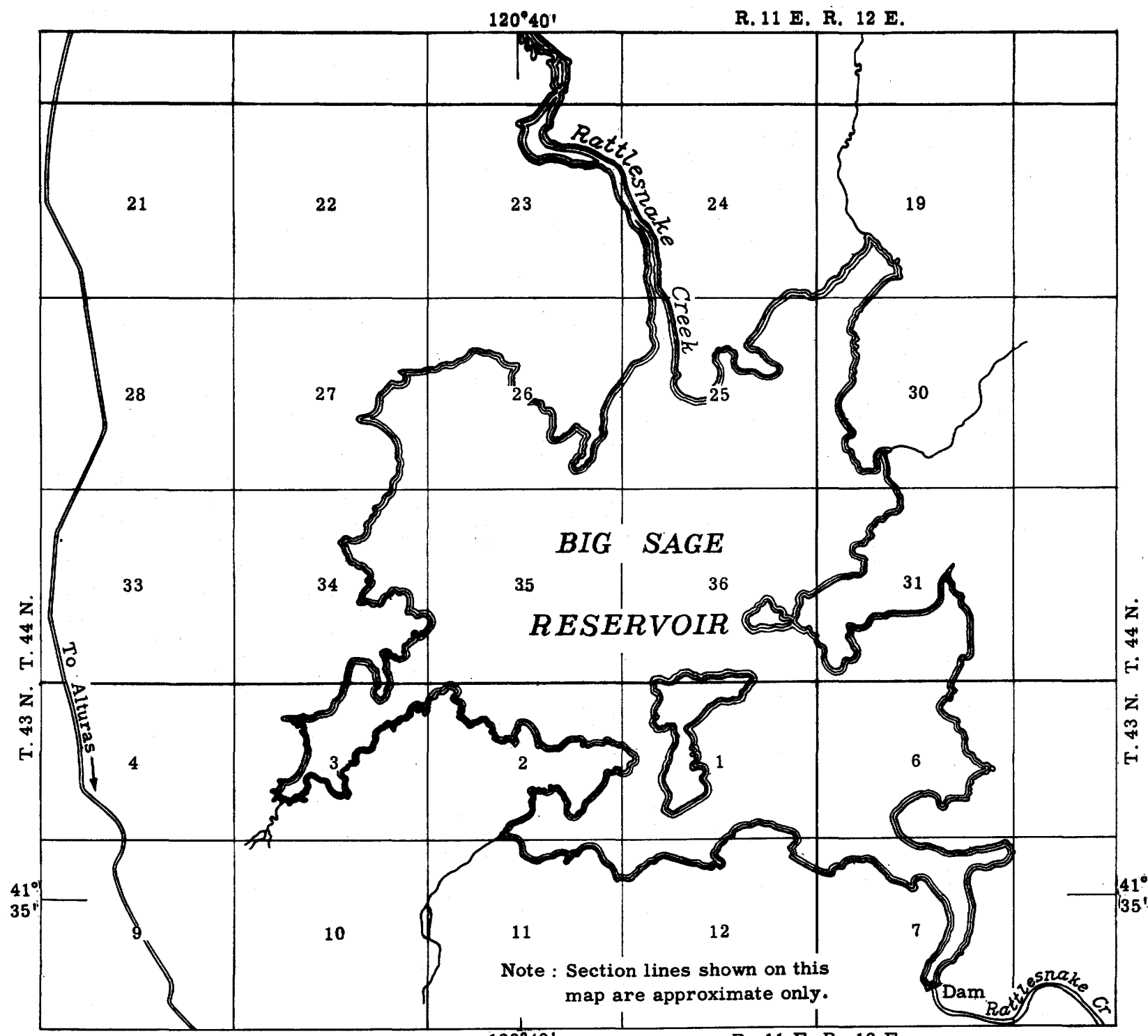

$120^{\circ} 40^{\prime}$ R. $11 \mathrm{E}$. R. $12 \mathrm{E}$.

$20,1,10$ Miles

Figure 12. -- Map of Big Sage Reservoir, Calif.

Russell's Warner basalt has a coarse columnar jointing and is vesicular. The vesicles are commonly net interconnected and do not cause the rock to be permeable, but the columnar jointing may. Ingerson (1932, p. 4) states that the basin is relatively impervious because of a surface accumulation of cementing ash and adobe soils. No ash was observed in the area visi ted on June 12, 1949, but it is believed that the underlying tuffaceous beds are relatively impermesble and provide an essentially watertight foundation. According to Ingerson, Supervising Hydraull c Engineer, California state $D_{1}$ vision of Water Resources, Sacramento, Calif., colloidal material remains In suspension in the reservolr indefinitely, regardiess of whether the water is disturbed or quiescent, and the reservolr bed has been virtually sealed.
If the basalt were sufficiently permeable to absorb and yield large quantities of water, springs should appear where the base of the basalt is exposed. No springs were seen along the bluffs north of the Alturas-Canby highway. According to silas B. Kelley, President, Hot Springs Valley Irrigation District, Alturas, Calif., prior to the construction of the dam in 192l Rattlesnake Creek ceased to flow in July or August, and no springs were known for several miles downst ream from the dam site. However, the Alturas reconnalssance sheet (1892), which was based in part on information obtained by the Wheeler Survey, shows several springs about 3 miles downstream from the dam 81 te. They are apparently at a somewhat higher elevation than the reservolr, although elevations shown on the Alturas reconnalssance sheet are admittedly not precise. Simpson reports 
that a spring in the reservoir site supplied the Woods ranch with sufficlent water to 1rr1gate 40 to 50 acres of meadow during the summer. It is presumed that this spring discharged water stored in the fractured basalt. Reports suggest that its flow was not greater than approximately 1 cub1 c foot per second. Ingerson estimates that the flow of small springs in the reservoir area totaled possibly 4 or 5 cublc feet per second.

There appears to be little seepage through and around the dam. A small seepage area marked by green grass and standing water was noted on the left bank 200 feet below the dam and 20 to 25 feet above the stream. There was no visible discharge. An inspection trip was made on foot for a distance of about 3,500 feet downstream from the dam. A small amount of side seepage is evident. A strip of green grass about 2,000 feet long and 40 feet in average width borders each bank of Rattlesnake Creek. Up to a helght of 3 to 5 feet above the stream bed, cattle hoofprints stand full of water, but no running water was observed. If the grassy strips, whose total area is approximately 4 acres, are supplied by seepage through or around the dam, as is likely, the volume of water thus consumed is probably about 10 acre-feet per year. However, seepage losses are apparentiy very small for, according to Ingerson, when the outlet valve in the dam is closed, the creek is dry below the dam.

About 2,000 feet downstream from the dam a grove of poplars lines the right bank of the creek for a quarter of a mile. These trees antedate the construction of the dam, and presumably are supplied from water stored in the basalt and resting on the tighter tuffs beneath.

The reservolr was inspected by boat. The surrounding terrain is quite flat, and the point at which Rattlesnake Creok enters the reservolr could not be located readily, so that ground-water conditions along the creek were not investigated. Seepage along the shoreline was noted at only one point, where three springs seeping from an amphitheatre-11ke area were discharging into the reservoir at a rate estimeted to be 0.05 cublc foot per second.

Total ground-water discharge from the reservolr is belleved negligible. Ground-water inflow cannot be measured precisely, but is certainly small. The surrounding terrain is quite flat, and storage of water in the reservolr has substantially decreased the hydraulic gradient causing the flow of the spring or springs known to have exl sted in the reservolr area. Although the quantities involved are quite small in comparison with evaporation during the summer, further investigation to determine the approximate spring discharge is warranted.

Flow of Rattlesnake Creek, a ccording to Ingerson, averages not more than 2 cublc feet per second during May and June, and is practically zero during July, August, and september. Records of contents in and outflow from the reservolr have been made avallable by $V$. $R$. Scammon, Watermaster, California State Division of Water Resources, Alturas, Cal1f.

Based on records for the years 1940-48, an approximate water budget for Apr1l-september has been calculated.
Quantity

(acre-feet)

Inflow:

Rattlesnake Creok

240

Rainfall on reservolr surface

Estl mated ground-water infl ow

1,200

300 Total

1,740

Outflow:

Reservolr relezses

8,350

The average decrease in reservolr contents during April-september for the years 1940-48 was 16,100 acre-feet. Average evaporation was $(1,740-8,350+16,100)$, or 9,490 acre-feet. The reservolr surface area a veraged 4,100 acre-feet. Bstlma ted average evaporation for this 5-month period was therefore 28 inches over the reservoir surface.

The three major 1tems in the water budget are the rainfali on the reservoir surface, change in reservoir contents, and reservoir releases. Rainfall on the reservoir surface doubtlessly can be measured with sufficient precision. Although existing area-capacity tables are quite adequate for the needs of the irrigation district, a hydrographic resurvey of the reservoir would be requi red, so that changes in reservoir contents could be measured with the degree of accuracy necessary for the water-loss studies. Reservolr releases are at present measured by means of an outletvalve rating. A continuous record of outflow can be obtalned below the dam, but the construction of an artificial control, possibly a Parshall flume, would be required. It is believed that the requirement that the error in the volumetric determination of evaporation shall not exceed 5 percent can be met.

The wind stmucture over Blg Sage Reservolr is not complicated by orographic effects. The reservolr is on a high plateau, and the slopes are gentle. Average January temperature at Alturas is $27.3^{\circ} \mathrm{F}$. and average July temperature is $67.3^{\circ}$ F. Rainfall averages 12.60 inches annually (Agriculture, 1941, p. 785).

Water temperature in the reservolr, measured on June 12, 1949, near the intake tower at a depth of approximately 6 inches, was $79^{\circ} \mathrm{F}$. The temperature of the water measured at the discharge end of the outflow plpe was $610 \mathrm{~F}$. A water sample was taken, and the results of the analysis made by the Geological Survey are as follows:

\section{Ion}

Parts per million

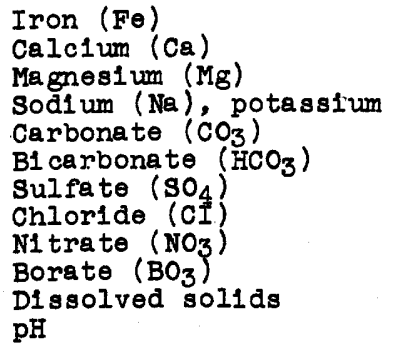

0.03
17
9.5
13
16
88
8
2
.1
$109^{.1}$
8.5

There are no recent maps of the reservolr area. Older maps show the reservolr to bo quite regular in shape. Aerlal photographs made september 20, 1948, when the reservo1r stage was approximately 10 feet below full 
The determination of the amounts of groundwater inflow and outflow, if any, would require an exhaustive study of the entire groundwater situation. Such a study might prove to be a monumental task because conditions are admittedly quite complex, and there is no positive assurance that results of the required degree of accuracy could be obtained at a reasonable cost. Because of the uncertainty in measuring ground-water flow, and because the lake is very shallow, Elsinore Lake was given no further consideration.

\section{IAKE MATHEWS, CALIFORNIA}

Lake Mathews, formed by Cajalco Dam, is 10cated about 10 miles southwest of Riverside, in Riverside County, Calif. The dam was completed in 1938 by the Metropolitan Water District of Southern California as a unit in the distribution of water from the Colorado River. The capacity of Lake Mathews is 107,000 acre-feet, and 1 ts surface area at splilway level is 2,020 acres.

It is supplied principaliy from the Los Angeles aqueduct through the val verde tunnel. Present operating practice is to maintain contents at approxime iely 85,000 to 100,000 a cre-feet. According to C. C. Elder, hydrographic engineer, Metropolitan Water District of Southern California, Los Angeles, Calif. annual inflow and outflow may total 100,000 acre-feet. In the ary months, monthly inflow and outflow may amount to 20,000 acre-feet and 15,000 acre-feet, respectively. Evaporation is estimated from pan records at about 8,000 acre-feet per year, with a maximum of 1,100 to 1,200 acre-feet per month. Thus errors of 1 percent in measuring monthly inflow and outflow may amount to about one-third of the evaporation during summer months. Although inflow and outflow are now measured with a precision quite adequate for operational purposes, it appears impracticable to measure the difference between inflow and outflow with the a ccuracy required for the water-loss study. In order to meet the requirement that the error in the difference between monthly inflow and outflow shall not exceed 5 percent of the monthly evaporation during the summer months it would be necessary that the error in measuring inflow and outflow not exceed about 0.2 percent, which appears impracticable.

The reservoir area is underlain by igneous rocks ranging from granite through granodiorite and gabbro, and a small body of tonalite. Seepage losses from the reservoir are not large and can be accurately measured. A detalled study of ground-water conditions would be required to demonstrate conclusively the possible magnitude of ground-water inflow from the Gavilan hills to the south.

Meteorological conditions at Lake Mathews are generaliy favorable. The surrounding terrain slopes gently, and the wind structure is believed to be uncomplicated by mechanically induced turbulence. Annual rainfall averages about 10 inches.

Lake Mathews was rejected as a site for the water-loss studies because of the impracticability of measuring inflow and outflow volumes with the required accuracy. In many other respects Lake Mathews is quite suitable, but the volumes of inflow and outflow are so large that the possible error in the difference between these two quantities is greatly magnifled.

\section{SALTON SEA, CALIFORNIA}

Salton Sea lies in a closed basin in southeastern California. In midale Tertiary time the Gulf of California extended much farther north than at present and included what is now the Salton Sea, according to Blake (1914, pp. 2-3). Later, as the continental land surface rose, the increased silt load of the Colorado River formed an immense delta. The head of the Gulf became an inland salt sea, fed at intervals by flood waters of the Colorado. Eventually, however, desiccation took place. Prior to 1905, large quantities of water reached salton sea only infrequently, according to Cory (1913, p. 1228). Its recent history has been described in detali by Mendenhall (1909, pp. 21-24), Brown (1923, pp. 3-12), and many others, with special reference to the Colorado River floods of 1905-06. During this period the floodwaters of Colorado River poured into the salton Sea, transforming it from an old dry lake, or playa, to the present large inland sea.

The elevation of the water surface of salton Sea in 1949 was approximately 240 feet below sea level. (See fig. 13.) The stage has varied little since 1944. At elevation -240 , the surface area of Salton Sea is 210,000 acres and 1 ts contents $4,033,000$ acre-feet.

The major source of surface-water supply of Salton Sea is dralnage from $1 \mathrm{rr}$ gated areas in the Imperlal Valley in the United States and Mexico. The dralnage enters Salton Sea in the channels of New and Alamo Rivers. Records of the Imperial Irrigation District show that for the 5-year perlod 1944-48 the average annual discharge into salton sea was 1,079,000 acre-feet. Whitewater River and San Felipe Creek flow directly into Salton Sea, but contribute substantial volumes of runoff only after infrequent storms. Peak discharge of Whitewater River at Point Happy, near Indio, during the January 1916 flood was 10,160 cublc feet per second, according to Talt (1917, p. 9).

The volume of ground-water inflow in the Coachella valley area is difficult, if not impossible, to estimate. According to Mendenhall (1909, p. 37), "there is a continuous slow movement of these subterranean waters beneath the Indio region toward the southeast, but the water does not escape to the gulf. Much the greater part of the subsurface percolation probably reaches the surface eventually in the vicinity of the Salton Sea, and before the inflow of the Colorado it escaped into the air by evaporation." The saturated sands average more than 1,000 feet in thickmess in an area of at least 400 square miles, Mendenhall estimated. Since the time of Mendenhall's report (1909), the ground-water resources of the Coachella valley have been extensively developed, and much of the water formerly reaching the salton sea area is now used for irrigation.

Ground-water inflow is not limited to the Coachella valley area. According to Brown (1923, p. 66), "Nearly every permanent or intermittent 


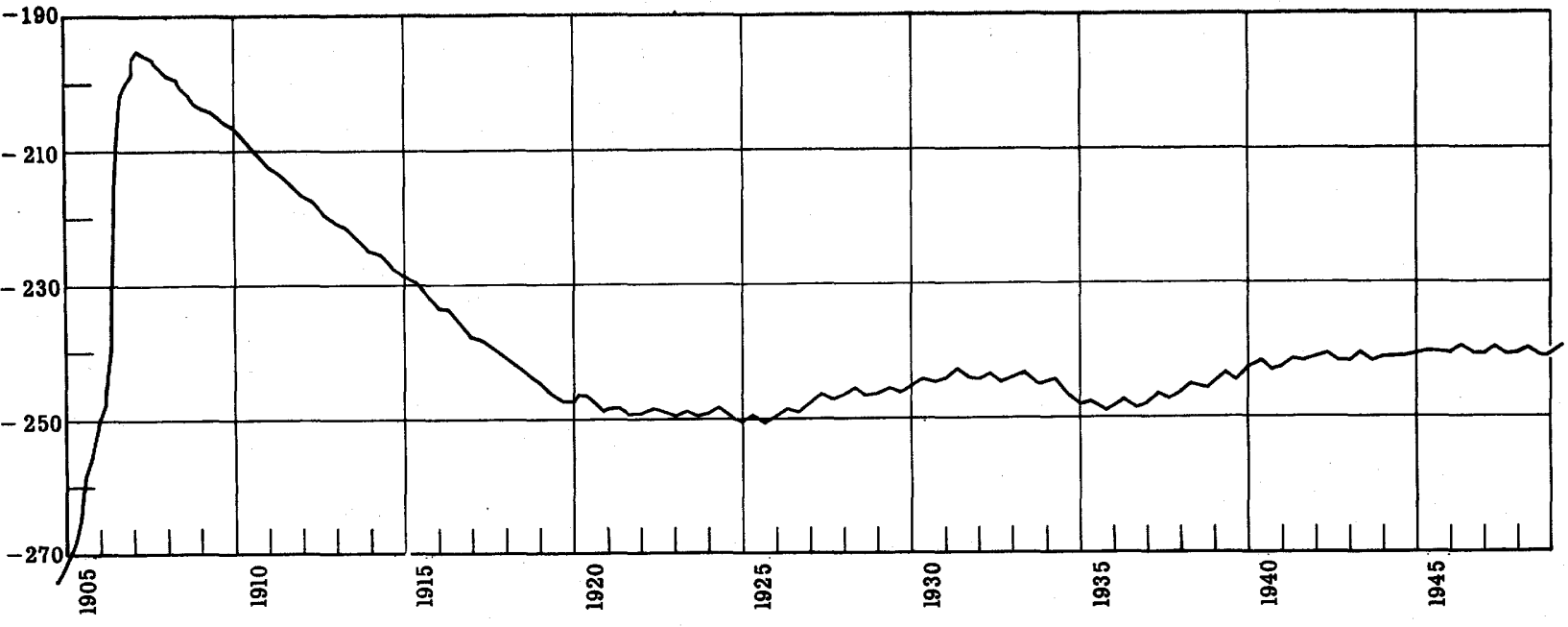

Figure 13. -- Graph showing stages of Salton Sea, Callf.

stream becomes interrupted in its lower portion as it nears the desert, because of gradual changes in the character of its bed and the increasing amount of porous gravel along 1ts course. Without exception; all the streams either sink completely into the desert soil or flow only in certain stretches before reaching their ultimate destination in the Salton Basin or other desert basins."

Estimates of evaporation from Salton Sea vary within rather wide limits. Annual evaporation from three screened pans in the vicinity of Salton Sea averaged 93.7 to 114.9 inches over a 2-year period, according to A. C. Bowen of the U.S. Soll Conservation Service, who states that a coefficient of 0.98 is applicable to this type of pan. Other evaporation-pan records obtained in this area indicate annual evaporation to be approximately 90 inches. IaRue (1916, p. 142) estimated annual evaporation from Salton Sea to be 5.8 feet, but his estimate appears low, for he did not take ground-water inflow into account. Normal evaporation from a Class-A pan, as taken from the map prepared by Horton (1943, p. 750, f1g. 2), is about 115 inches per year. Using a coefficlent of 0.7 , equivalent reservolr evaporation is 80 inches. Mean annual evaporation in the Salton Sea area, as taken from the map prepared by Mejer (1942, map 4), is approximately 85 inches per year.

For the purpose of estimating the possible magnitude of unmeasured surface- and groundwater inflow into Salton Sea, annual evaporation is taken as 80 inches. During 1944-48, the surface area of Salton sea remained fairly constant at about 200,000 acres. Average annual evaporation is therefore estimated to be 1,330,000 acre-feet. Measured inflow during this period averaged $1,079,000$ acre-feet per year. Since the contents of the sea did not change substantially during this period, unmeasured inflow apparently averaged 250,000 acre-feet per year. However, a computation of this nature is subject to gross errors, for an error of 6 inches in the estimated evaporation would result in an erros of 100,000 acre-feet in the estimate of unmeasured inflow.

The fact remains, however, that since the stage of Salton Sea has remained relatively constant during the last few years, evaporation must approximately equal inflow. For the purposes of this study it is required that the maximum allowable error in measuring evaporation by volumetric means must not exceed 5 percent of the actual evaporation. It appears that a measurement of this accuracy for Salton Sea is impracticable. Most of the surface inflow is now measured by the Imperial Irrigation District. Even if the infrequent periods of storm runoff are excluded from the accounting, an extensive network of stream gaging stations would be required merely to demonstrate conclusively the occurrence or nonoccurrence of storm runoff. Although each gaging station could be of extremely simple construction, many would be required, and the total cost would be high.

The problem of measuring ground-water inflow is immensely more difficult. Considerable fleld study would be required to select proper sites for a network of observation wells. Pumping tests would be necessary for permeability determinations. Continuous records of water-level elevations would be required. Admittedly a costly undertaking, it has the more serlous drawback that there is no positive assurance that results would be of the necessary high degree of accuracy.

The large size of Salton sea poses some problems in connection with the meteorological observations to be made as a part of the water-loss study. The number of meteorological observation stations deemed adequate for a lake of say 10 square miles surface area is Inadequate for a water surface as large as Salton Sea. Preliminary field studies of the areal variations in meteorological elements 
might be needed before a decision could be reached as to the number and location of observation stations. A hydrographlc survey of salton sea would be required. With modern equipment the task would be essentially routine in nature, despite 1ts magnitude. Another problem complicated by the size of Salton sea 1s the precise determination of stage. Selche amplitudes may be fairly high. In addition to a number of gages along the shores, it would appear essential that some method be devised for the precise measurement of stages at points on the lake in order to obtain a true picture of the surface, whether flat or tilted, or warped by wind action.

The decision to eliminate Salton Sea from further consideration as a site for the waterloss investigations was, therefore, based primarily on the belief that it would be impracticable to determine the water budget with the required degree of accuracy. The problems arising from the great size of Salton Sea are not considered unsurmountable.

\section{OTHER RESERVOIRS}

Many other reservoirs and lakes were suggested for consideration as possible sites for the water-loss study. They were rejected because of failure to meet the specifications in one or more respects. Brief comments on many of the suggested lakes have been prepared to indicate the principal reason for eliminating them from further consideration. Many of ihe (w) reservolrs and lakes may also fall to meet the specifications in respects other than those mentioned, but detalied studies were not made if preliminary investigations indicated that the lake was unsultable because of size, shape, or the impracticablilty of determining an accurate water budget.

\section{Arizona}

Green Reservolr.--Abandoned.

Mormon Lake.--Dry in 1947; little water in 1949. Very shallow, saucer-shaped basin; small changes in stage result in large changes in surface area.

Roosevelt Reservo1r.--Iong, narrow; prevalling winds at right angles to long axis; large fluctuation in stage.

\section{California}

Buena Vista Lake.--Dry in 1949 and will not contain water again until a fairly large flood occurs in Kern River.

Butte Lake.--Formerly a shallow reservoir but now abandoned.

Calaveras Reservoir.--Sma11; surface area slightly more than 2 square miles; inflow and outflow are large compared with evaporation. Clear Lake (Cache Creek).--Ground-water movement into or out of Quaternary deposits may be substantial and would be difficult to measure accurately; irregular shape; mountains on three sides.

Clear Lake (Lost River).--Irregular shape; islands and shorls divide lake into two basins; adjacent swamp is larger than lake.

Copper Basin Reservoir.--Small; surface area less than I square mile.

Crystal Spring Reservolr.--Small; surface area slightly more than 2 square miles; inflow and outflow large compared wi th evaporation.
Fagle Lake.-.Very irregular shape; large ground-water outrlow.

East Park Reservo1r.--Small; surface area less than 3 oquare m11es at full pool; largo 1rr1gation withdrawals.

Harfleld Reservolr.--Contains no water other than Infrequent waste from Colorado River Aqueduct.

Honey Lake.--Irregular shape; dry in September 1949.

Horse Lake.--Dry in 1949; very 1rregular shape. Kern Lake. - Generally dry or nearly so.

Lake Almanor.--Mountain reservoir; extremely Irregular shape.

Lake Arrowhead.--Small; surface area slightly more than I square mile.

Lake Henshaw.--Subsurface inflow during la to summer months may amount to 25 percent of the evaporation.

Lake Levitt.--Small; large irrigation withdrawals.

Lake Pillsbury.--Irregular shape; inflow and outflow large in comparison with evaporation. Lake Tahoe.--Large; surface area 193 square miles. Inflow and outflow large compared with evaporation; inflow difficult to measure. Mesquite Lake.--Dry in 1949.

Mono Lake.--Many springs in lake bottom. Morris Reservolr.--Canyon reservolr. Mountain Meadows Reservolr.--Shallow; average depth about 4 feet when reservoir 1 s full. Owens lake.--Shallow; average depth less than 10 feet; mountain ranges rise 6,000-7,000 feet above lake on east and west.

Prado Reservolr.--Flood-control reservolr; normally empty.

Salinas Reservolr.--Canyon reservolr.

Shasta Reservoir.--Very irregular shape; canyan reservolr; probable errors in measuring inflow and outflow large compared with evaporation.

Stony Gorge Reservolr.--Canyon reservolr. Tinnemaha Reservolr.--Small; inflow and outflow large in comparison with evaporation.

\section{Colorado}

Green Mountain Iake.--Inflow and outflow very large compared with evaporation. John Martin Reservo1r.--Irrigation withdrawals occasionaliy reduce contents to zero.

\section{Idaho}

Bear Lake.--Impracticable to determine surfaceand ground-water inflow and outflow with required accuracy; large shallow areas with water-using vegetation.

Blackfoot Marsh Reservo1r.--Irregular shape; subsur face losses difficult to determine.

Coeur d'Alene Lake.--Extremely irregular shape. Crane Creek Reservoir.--Long, narrow; inflow and outflow large compared with evaporation. Deer Flat Reservoir.--Large and variable subsurface losses.

Grays Lake.--Iarge shallow areas; considerable portion of lake area covered with tules.

Hayden Lake.--Repor ted to have la rge subsurface losses, particularly at high stages; surrounding terrain mountalnous.

Henrys Lake.--Ground-water inflow and outflow difficult to determine a ccurately.

Island Park Reservolr.--Iarge changes in bank storage.

Magl c Reservolr.--About $8 \mathrm{miles}$ long and up to 2 miles wide with long axis approximately at right angles to prevailing winds; shore ine irregular.

Mud Lake:-Substantial ground-water inflow, difficult to measure. 
M1 s sour1

Wappapel10 Reservo1r.--Long, narrow; very Irregular shore I1ne; humid climate; Inflowoutflow difference cannot be measured with sufficient accuracy.

\section{Montane}

Deadmans Bas1n.--Small; surface area less than 3 square miles.

Hebgen Reservo1r.--Irregular shape; mountain reservoir.

Plshkun Reservolr.--Small; surface area less than 3 square miles.

Ruby Reseryolr.--Small; surface area less than I square mile.

Swan Lake.--Iong, narrow; mountain lake. Tongue RIver Reservolr.--Long, narrow; 1rregular shore line.

Willow Creek Reservolr (Sun River).--Small; less than 3 square miles.

\section{Nebraska}

Johnson Reservoir.--Inflow and outflow very large in comparison with evaporation. McConaughy Lake.--Considerable bank storage; long, narrow; Irregular shore line; prevalilng summer winds across long axis.

Sutherland Reservolr.--Substantial subsurface losses.

\section{Nevada}

Carson Lake.--Large subsurface return flow from irrigation; large area of water-using vegetation.

Lahontan Reservo1r.--Long, narrow; 1rregular shape.

Lake Tahoe.--See list of Cal1formia lakes and reservoirs.

Rye Petch Reservo1r.--Iong, narrow; 1rregular shore line.

Snow Water Lake.--Supplied mainly by subsurface flow; dry much of the time.

Washoe Lake.--Iarge subsur face inflow; very shallow; large areas of water-using vegetation.

\section{New Mexico}

Alamogordo Reservolr.--Long, narrow; 1rregular shore line; prevailing sumer winds normal to long axis of lake.

Blue Water Lake.--Irregular shore line; broken terrain; subsurface losses reported to be of considerable magnitude.

Caballo Reservolr.--Long, narrow; rugged terrain; Irregular shore line; subsurface inflow from Black Range on west.

Conchas Reservolr.--Two arms nearly at right angles; shore line very irregular.

El Vado Reservoir.--Long, narrow; irregular shore Ilne.

Elephant Butte Reservolr.--Long, narrow;

mountains on east side; subsurface inflow from Black Range on west; transpiration losses large. Hondo Reservolr.--Seldom contains water.

Lake McMIIlan.--Used for temporary detention only.

\section{North Dakota}

Devils Lake.--Magnitude of surface- and groundwater inflow and outflow uncertain and difflcult to measure; irregular shore line with large bays and arms, which may be separated from main body of water during dry years.
Oklahoma

Great Salt Pla1ns Reservolr.--Inflow and outIllow very large compared WI th ovaporation and cannot be measured accurately.

\section{Oregon}

Agency Lake.--Large swampy areas bordering lake. Agencr Valler Reservo1r.--Small; surface area at full pool less than 3 square miles; large w1 thdrawals for ir rigation during sumer months.

Antelope Reservo1r.--Large 1 rrigation withdrawals during summer months; reported dry In late summer of 1949.

Cottage Grove Reservoir.--Small; surface area

less than 2 square miles.

Crater Lake.--Substantial portion of inflow belleved lost by seepage; surrounded by escarpment from 500 to 2,000 feet high.

Drew Reservolr.--Long, narrow; very shallow on west side; apparently considerable groundwater inflow.

Fern Ridge Reservolr.--Very shallow; considerable marginal vegetation; large drawdown in winter; may be considerable bank storage in terrace gravels along east shore.

Gerber Reservolr.--Very Irregular shape; too small in September 1949 because of large 1rrigation withdrawals.

Malhour Lake.--Very shallow, if not dry; occasional outflow to Harney Lake difflcult to measure a ccurately.

Owyhee Reservolr.--Iong, narrow; canyon reservo1r.

Summer Lake.--Practically dry in September 1949. Upper Klamath Lake.--Considerable marginal vegetation; shallow; irregular shape. Warmsprings Reservolr.--Large irrigation withdrawals in late summer; contents only about 7,000 acre-feet in August 1949 .

Wícklup Reservo1r.--Substantial subsurface Inflow and outflow.

\section{Texas}

Barker Reservo1r.--Detention reservoir with no provision for permanent storage. Bridgeport Reservolr.--Very ir regular shape. Brownwood Reservolr.--Irregular shape; inflow and outflow large compared with evaporation. Buchanan Reservoir.--Irregular shape; inflow and outflow large compared with evaporation. Buffalo Lake.--Small; surface area about 3 square miles when reservolr contents are 18,150 acre-feet, but contents usualiy much less than this.

Eagle Mountain Reservoir.--Long, narrow; irregular shore line.

Fort Phantom Hill Reservoir.--Irregular shape; small; surface area less than 4 square miles on September 30, 1949 .

Lake Abilene.--Small; surface area less than I square mile.

Lake Dallas.--Inflow and outflow large compared with evaporation.

Lake Kemp.--Extremely 1 rregular shape.

Lake Kickapoo.--Long, narrow; Inflow occasionally very large in comparison with evaporation. Lake Klrby.--Small; surface area less than 1 square mile.

Lake Travis.--Very irregular shape.

Possum Kingdom Reservolr.--Very irregular shape. Red Bluff Reservoir.--Monthly changes in

contents very large in comparison with evaporation.

San Angelo Reservoir.--Not yet completed in spring 1950 . 
Utah

Bear Lake.--See Idaho list of lakes and reservoirs.

Deer Creek Reservol r.--Canyon reservoir. Hyrum Reservo1r.--Small; surface area less than 1 square mile.

Midview Reservo1r.--Small; surface area less

than i square mile.

Salt Lake.--Usually dry.

Sevier Bridge Reservolr.--Long, narrow; has been dry at times.

Sevier Lake.--Usually contains little, if any, water.

Strawberry Reservoir.--Inflow and outflow large compared with evaporation, which is reported to be low; elevation 7,500 feet.

Utah Lake.--Shallow; a verage depth less than 10 feet. Subsurface inflow difficult to determine.

Washington

Blue, Lenore, and Soap Lakes.--A chain of elongate lakes in the lower and south half of the Grand Coulee; shape and topographic setting unsatisfactory.

Moses Lake.--Irregular shape.

Wyoming

Jackson Lake.--Irregular shape; many tributary streams.

Lake Hattie.--Seldom contains any large quan-

tity of water.

Wyoming Development No. 2.--Iong, narrow

reservolr; inflow and outflow large compared with evaporation.

Wyoming Development No. 3.--Irregular shape;

inflow and outflow large compared with evaporation.

\section{REFERENCES CITED}

Amerlcan Soclety of Civil Engineers, 1949, Hydrology Handbook, ASCE Manual of Engineering Practice No. 28.

Anderson, E. R., Anderson, I. J., and Marciano, J. J., 1950, A review of evaporation theory and development of instrumentation: U. S. Navy Electronics Lab. Rept. No. 159 (free on application to U. S. Geol. Survey, Washington $25, \mathrm{D}$. C.).

Antevs, E. V., 1938, Rainfall and tree growth in the Great Basin: Carnegle Inst. Washington Pub. No. 469 .

Blake, W. P., 1914, The Cahullia Basin and Desert of the Colorado, in MacDougal, D. T., The Salton Sea: Carnegie Inst. Washington Pub. No. 193.

Brown, J. S., 1923, The Salton Sea region, Calif.: U. S. Geol. Survey Water-Supply Paper 497 .

Congressional documents: 72d Congress, lst sess., H. Doc. 191, 1932.

Cory, H. T., 1913, Irrigation and river control in the Colorado River delta: Am. Soc. Civ. Eng. Trans., vol. 76.

Dobbin, C. E., and Erdmann, C. E., 1946, Structure contour map of the Montana plains, U. S. Geol. Survey geophysical investiga- t1ons map..

Erdmenn, C. E., Davis, N. A., Beer, Wm., and Nordquist, J. W., 1946, Preliminary structure contour map of the Cut Bank-- West Kevin border districts, U. S. Geol. Survey geophysical investigations map.

Harding, S. T., 1922, Report on San Jacinto River Hydrographic Investigation: California Div. of Water Rights.

Harding, S. T., 1927, Evaporation on Reclamation projects (discussion): Am. Soc. Civ. Eng. Trans., vol. 90.

Harding, S. T., 1935, Evaporation from large water surfaces based on records in California and Nevada: Am. Geophys. Union Trans., pt. 2.

Horton, R. E., 1943, Evaporation maps of the Uni ted States: Am. Geophys. Uni on Trans., pt. 2 .

Ingerson, I. M., 1932, Report on supervision of diversions from P1t River and Rattlesnake Creek in Hot Springs Valley, Modoc County, Calif., 1931 season: State of Callfornia Div. of Water Resources Rept. (mimeographed).

Jones, J. C., 1925, Quaternary climates: Geologlc history of Lake Lahontan, Carnegie Inst. Washington Pub. No. 352.

Langbein, W. B., 1949, Annual runoff in the Uni ted States: U. S. Geol. Survey Circ. 52.

LaRue, E. C., 1916, Colorado River and 1 ts utilization: U. S. Geol. Survey Water-Supply Paper 395.

Meinzer, 0. E., Ground water, in Physics of the Earth, Nat. Research Counc1l, McGrawH1Il, 1942, reprinted by Dover Publications, Inc., 1949 .

Mendenhall, W. C., 1909, Ground waters of the Indio region, Callf.: U. S. Geol. Survey Water-Supply Paper 225.

Meyer, A. F., 1942, Evaporation from lakes and reservolrs: Minnesota Resources Comm.

Russell, I. C., 1884, A geological reconnaissance in southern oregon: U. S. Geol. Survey 4 th Ann. Rept.

Russell, I. C., 18u5, Geological history of Lake Lahontan: U. S. Geol. Survey Mon. Il.

Russe11, R. J., 1928, Bas in range structure and stratigraphy of the Wamer Range, northeastern California: California Univ., Dept. Geol. Sc1, Bull. vol. 17 .

Schanck, F. R., 1919, in Waring, G. A., Ground water in the San Jacinto and Temecula Basins, Callf.: U. S. Geol. Survey Water-Supply Paper 429 .

Sverdrup, H. U., 1945, Oceanography, in Handbook for Meteorologists, lst ed., McGrawHill.

Tait, C. B., 1917, Preliminary report on conservation and control of flood water in Coachella Valley, Calif.: 5th Blenn. Rept., California Dept. Eng., Appendix D. 
U. S. Dept. Agr., 1941, Climate and Man: 1941 Yearbook of Agriculture.

U. S. Dept. Commerce, Weather Bur., 1848, Cl1matological data, vol. 35, No. 13.

U. S. Geol. Survey, 1949, Surface-water supply of the United States, 1947, Water-Supply Paper 1091.
Warling, G. A., 1908, Geology and water resources of a portion of south-central orezon: U. $S$. Genl. Survey Water-Supply Paper 220.

Waring, G. A., 1819, Ground water in the San Jacinto and Temecula Basins, Calif.: U. S. Geol. Survey Water-Supply Paper 429.

Zander, Gordon, 1933, P1t River Investigetion: State of Californla Div. of Water Resources. BuII. 41. 
